\title{
Effect of temperature on the interactions between beet cyst nematodes (Heterodera schachtii and Heterodera betae) and sugar beet
}

\author{
Dissertation \\ to obtain the Ph.D. degree \\ in the Ph.D. Program for Agricultural Sciences in Göttingen (PAG) \\ at the Faculty of Agricultural Sciences, \\ Georg-August-University Göttingen, Germany
}

Presented by

Bart AB Vandenbossche

Born in Gent, Belgium

Göttingen, May 2016 
D7

1. Examiner:

Prof. Dr. Stefan Vidal (Promoter)

Department of Crop Sciences, Division of Agricultural Entomology, University of Göttingen, Germany

2. Examiner:

Prof. Dr. Johannes Hallmann

Fachgebiet Ökologischer Pflanzenschutz

University of Kassel, Witzenhausen

3. Examiner:

Prof. Dr. Andreas von Tiedemann

Director of the Department of Crop Sciences, Division of Plant Pathology and Crop Protection, University of Göttingen, Germany

Place and date of defense: Göttingen, 11 May 2016. 


\section{Table of Contents}

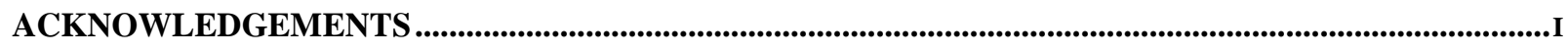

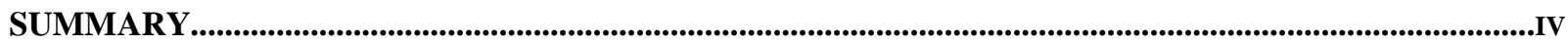

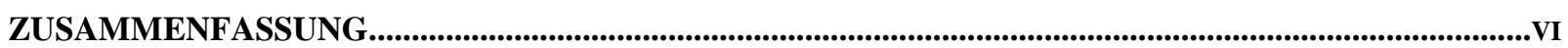

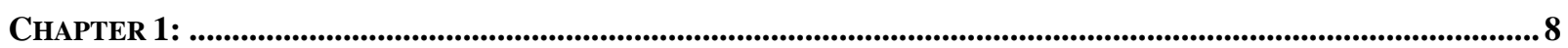

GENERAL INTRODUCTION .................................................................................................................................

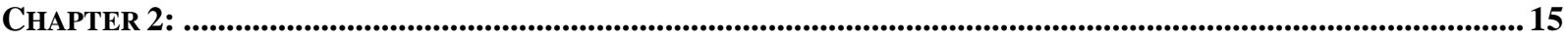

EFFECT OF TEMPERATURE ON THE HATCH OF TWO GERMAN POPULATIONS OF THE BEET CYST NEMATODES,

HETERODERA SCHACHTII AND HETERODERA BETAE .................................................................................... 15

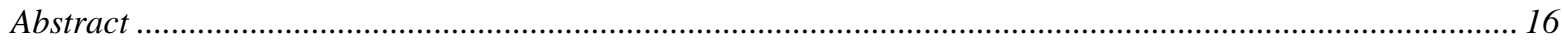

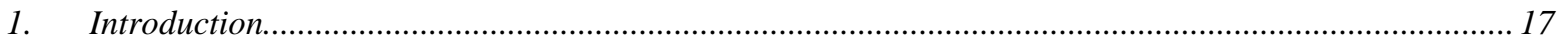

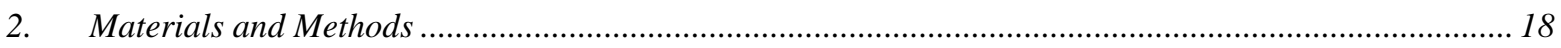

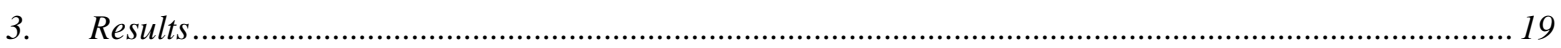

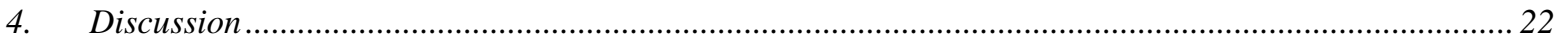

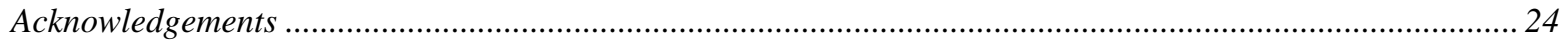

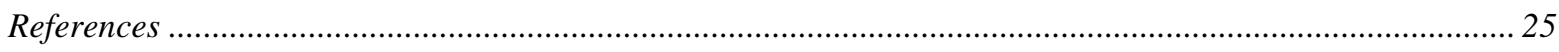

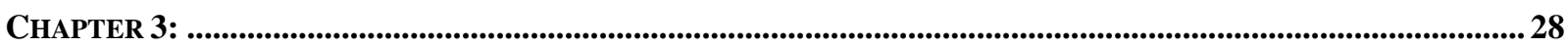

INFLUENCE OF EXPERIMENTAL SOIL WARMING ON POPULATION DENSITY OF HETERODERA SCHACHTII AND THE

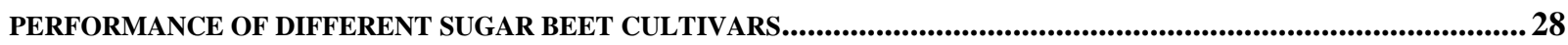

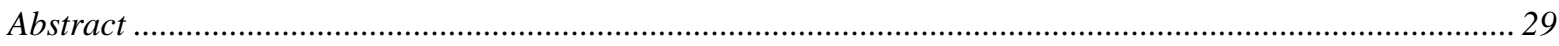

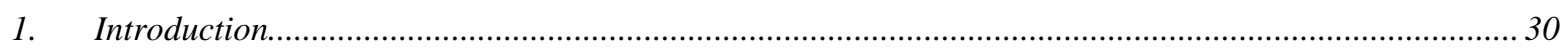

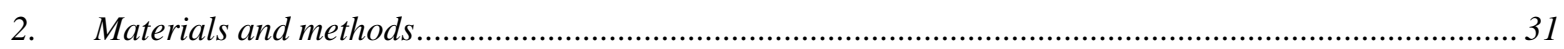

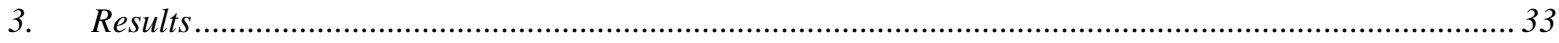

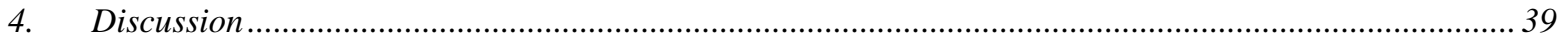

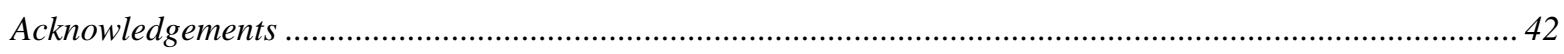

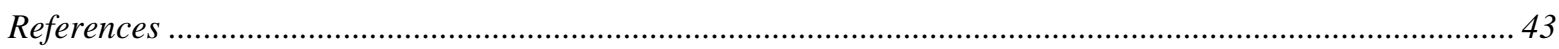

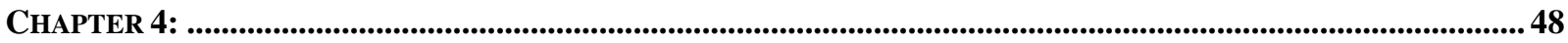

INFLUENCE OF TEMPERATURE ON THE INTERSPECIFIC COMPETITION BETWEEN THE BEET CYST NEMATODE SPECIES HETERODERA SCHACHTII AND HETERODERA BETAE ON SUGAR BEET ........................................................ 48

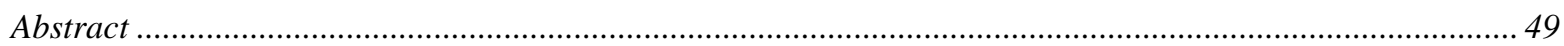

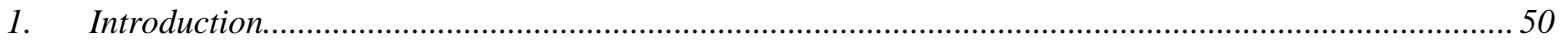

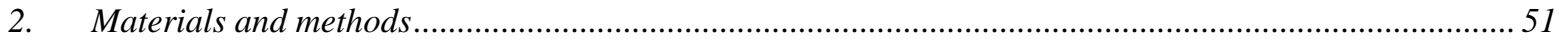

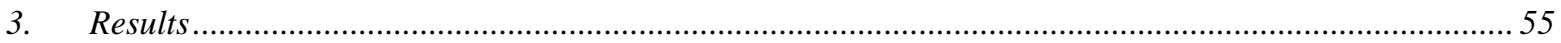

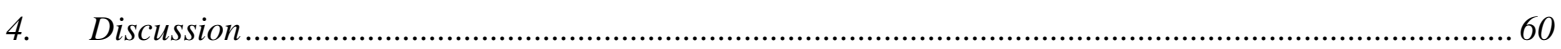

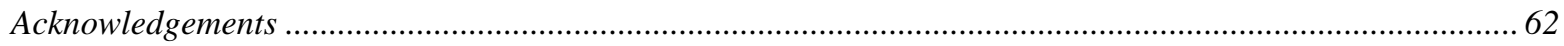




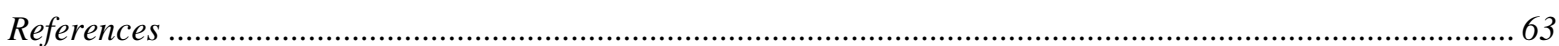

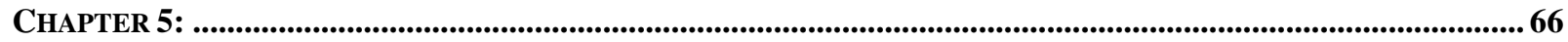

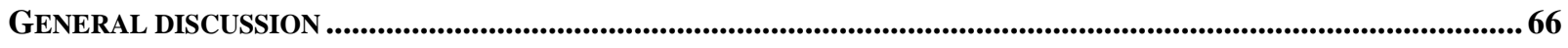

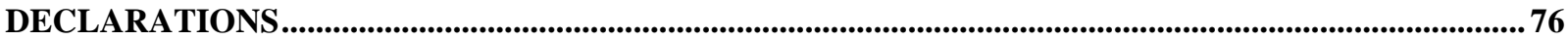




\section{ACKNOWLEDGEMENTS}

A thesis is actually expected to strive for brevity. However, I want to make an exception when it comes to thanking all people who helped and supported me in making this work come true.

First of all, I would like to thank two people who were closely involved with my work: my supervisor Dr. Björn Niere and my promoter Prof. Dr. Stefan Vidal.

Stefan, I would like to thank you for taking me up as your "Doktorsohn" and encouraging me throughout the thesis. Thank you for your guidance and directions in the development of the research and the manuscripts Thanks for all logistic support at the University. It was every time a pleasure to come visiting your group during seminars and courses.

Björn, thank you for taking me as your student and introducing me in the JKI Braunschweig. You were there for me from the absolute beginning until the end. Your practical advice and countless suggestions not only developed the research path but also made me grow as a scientist. You taught me to keep it simple when I tended to make it too complicated. You supported me in practicing the German language in both small- and scientific talks.

My gratitude also goes to Dr. Holger Heuer, for teaching and guiding me in the molecular world. Thank you for your valuable advice and suggestions.

Special thanks also come to Dr. Bernd Ulber, which helped me a lot with administrative tasks and his advice during seminars and visits are highly appreciated

Prof. Dr. Johannes Hallmann, I would like to appreciate you for accepting to be my cosupervisor.

Prof. Dr. Andreas von Tiedemann thanks for accepting to be a serving committee member.

Thanks to all colleagues and friends at the Julius Kühn Institute and in special the Institute for National and International Plant Health, Braunschweig. 
Special thanks to my PhD-partners in the lab, Peter, and Mohamed, for all scientific and friendly support. Peter, thank you for always being there to give a helping hand, a listening ear and to be a great friend.

Steffi and Martin, you are earning a special mentioning in this list. Steffi the lunch breaks in the "Kantine" and the badminton games were a real joy and refreshment. Thank you for proofreading and improving several chapters. You became very close friends and welcomed me always as family for all short and longer stays.

Thanks also to all colleagues at Göttingen University. Thank you Antje for offering accommodation during longer stays in Göttingen. Thanks to Ms. Schachtebeck for all her kind help.

The financial support of the Ministry for Science and Culture of Lower Saxony, Germany, within the research network "KLIFF" - climate impact and adaptation research in Lower Saxony" is gratefully acknowledged.

Thanks to the colleagues at E-nema for believing in me and encouraging me.

Gracias a todos en el IIAG-CSIC en Santiago de Compostela por ofrecerme la biblioteca completa para escribir.

Thanks to the whole "Equipo" for all refreshing drinks, dinners, and trips in Braunschweig and beyond. Mr. Ding and Hannes thank you for coming in the camino-short edition. What about the long edition?

Thanks to Juinke, Breght, Bob, Kim and Tom et al for keeping the comradeship alive, in or outside the Bagattos. I know that I stepped out of several activities and travel plans because of the thesis, so let's see if we can do some re-takes mixed with new crazy ideas. Thanks also to Annie, Rudy, Kristien en buren for all support. 
Graciñas a María Elena, Pepe, Martín y Alba por ser tan buenos y por creer en mí. Graciñas también a toda la familia y amigos en Galicia y España.

Mijn moeder Gina, mijn vader Filip, mijn zus Inge en mijn familie zijn van onschatbare waarde voor mij. Hun kan ik niet genoeg bedanken voor hun niet aflatende steun, geduld en luisterend oor. Zowel mijn thuisbezoekjes als jullie bezoekjes hebben meer dan eens de batterijtjes opgeladen. Mijn vader wordt hard gemist. Deze is ook voor jou en mama.

Maria, I don't know how I can possibly thank you for all your support during all this time. We have been through a lot of adventures and countries the past years. Thank you for lighting and spicing up my life and being always there for me. Life is just so much better with you. Thank you for always believing in me and for all your help and patience during this Ph.D. Now it is your time and I am sure you will do a great job!

Bart AB Vandenbossche

6 March 2016 


\section{SUMMARY}

Climate change is expected to cause a mean annual temperature increase in Germany of $2{ }^{\circ} \mathrm{C}$ by 2050 and up to $4{ }^{\circ} \mathrm{C}$ by 2100 . This is likely to have effects on crop development and pathogen development as well. For this Ph.D. thesis, experiments were conducted to investigate the effect of increasing temperatures on the beet cyst nematodes Heterodera schachtii and Heterodera betae and thus study the changes of their interaction with their host plant the sugar beet (Beta vulgaris subsp.).

Differences in hatch between the beet cyst nematode species were assessed at constant temperatures in incubators as well as simulated temperature conditions set to be $4{ }^{\circ} \mathrm{C}$ higher than the standard temperature regime.

The optimal temperatures for hatch were found to be different for both cyst nematode species. The optimal temperature range for hatching of $H$. schachtii was found to be between 15 and 30 ${ }^{\circ} \mathrm{C}$ and for $\mathrm{H}$. betae between 20 and $30{ }^{\circ} \mathrm{C}$. Emergence of juveniles of both beet cyst nematode species began at $5{ }^{\circ} \mathrm{C}$, however in very low percentages. For both beet cyst nematode species no significant differences were found in the final cumulative hatch percentages when comparing the standard temperature regime with the by $4^{\circ} \mathrm{C}$ increased temperature regime.

In the climate chambers, the influence of temperature on the interspecific competition between both beet cyst nematode species was studied. Both beet cyst nematode species performed better at higher temperatures. But there were no clear indications that under competition one of the two species will profit more from higher temperatures under the predicted climate change.

In conclusion, the damage done by cyst nematodes in sugar beet is expected to increase with global warming. $H$. schachtii and $H$. betae are likely to continue to cause damages. But in competition, neither of the two species will profit more from rising temperatures compared to the other.

The effect of experimental soil warming on $H$. schachtii population development and sugar beet performance was assessed for sugar beet cultivars that were susceptible, tolerant or resistant to $H$. 
schachtii. In this study, soil heating lead to a significant increase in the final number of recovered cysts on the tolerant cultivar and susceptible cultivar. The resistant cultivar did not allow nematode reproduction at all. Therefore no effect of soil heating could be detected. Plantnematode interaction varies greatly depending on the cultivar. Thus cultivar choice is an important element when trying to prevent nematode infestation or controlling nematode populations in the field. In case of high nematode population densities and with the expected increasing soil temperatures, planting nematode-resistant cultivars will become even more important in the future, as an effective tool to reduce nematode populations and prevent damages. 


\section{ZUSAMMENFASSUNG}

Für Deutschland wird vorausgesagt, dass der Klimawandel eine Erhöhung der Jahresmitteltemperaturen um $2{ }^{\circ} \mathrm{C}$ bis zum Jahr 2050 und sogar um $4{ }^{\circ} \mathrm{C}$ bis zum Jahr 2100 bewirken wird. Dies bleibt nicht ohne Einfluss auf die Entwickelung von Kulturpflanzen und ihre Schaderreger. Ziel dieser Doktorarbeit war es, in verschiedenen Versuchen den Einfluss von erhöhten Temperaturen auf die Entwicklung der Rübenzystennematodenarten, Heterodera schachtii und Heterodera betae zu simulieren und Aussagen über die Veränderungen in der Interaktion mit ihrer Wirtspflanze, der Zuckerrübe (Beta vulgaris subsp.) zu treffen.

Unterschiede im Schlupfverhalten beider Rübenzystennematodenarten wurden ermittelt sowohl unter konstanten Temperaturbedingungen in Inkubatoren als auch in Klimakammern. In den Klimakammern wurde eine Erhöhung von $4{ }^{\circ} \mathrm{C}$ gegenüber den Standardtemperatur simuliert.

Die optimale Temperaturen für den Schlupf waren unterschiedlich für beiden Arten. Für Heterodera schachtii lagen sie zwischen $15^{\circ} \mathrm{C}$ und $30^{\circ} \mathrm{C}$. Für $H$. betae wurden die höchsten Schlupfraten bei Temperaturen zwischen $20^{\circ} \mathrm{C}$ und $30{ }^{\circ} \mathrm{C}$ beobachtet. Beide Arten begannen bei $5{ }^{\circ} \mathrm{C}$ zu schlüpfen, allerdings war der Prozentsatz der geschlüpften Tiere äußerst niedrig. Für beide Arten waren keine signifikanten Unterschiede in den finalen kumulativen Schlupfraten zwischen das um $4{ }^{\circ} \mathrm{C}$ erhöhte Temperaturregime und das Standardtemperaturregime in den Klimakammerversuchen zu erkennen.

In den Klimakammern wurde der Einfluss der Temperaturerhöhung auf die Konkurrenzfähigkeit beider Arten studiert. Es zeigte sich, dass die Populationsdichten beider Arten mit höheren Temperaturen anstiegen. Es ist $\mathrm{zu}$ erwarten, dass beide Rübenzystennematoden vom Klimawandel profitieren werden und daher verstärkt Schäden in Zuckerrüben verursachen werden. Die vorliegenden Ergebnisse zur Wettbewerbsfähigkeit der beiden Arten lassen keine Rückschlüsse darauf zu, dass eine der beiden Spezies stärker vom Klimawandel profitiert als die andere.

In den Experimenten wurde der Einfluss von erhöhten Bodentemperaturen auf die Populationsentwickelung von Heterodera schachtii an verschiedenen Zuckerrübensorten bewertet, nämlich an einer empfindlichen, einer toleranten und einer resistenten Sorte. An der toleranten und der empfindlichen Sorte führte die experimentelle Erwärmung des Bodens zu 
deutlich gesteigerten Zystenzahlen an den Rübenwurzeln. Die resistente Sorte hingegen ließ unabhängig von der Bodenerwärmung keine Nematodenvermehrung zu. Im Fall eines hohen Infektionsdruckes, also bei hohen Nematodenzahlen im Boden und angesichts der prognostizierten steigenden Bodentemperaturen, wird der Anbau von resistenten Zuckerrübensorten zukünftig noch mehr an Bedeutung gewinnen. Die kluge Sortenwahl, also der Anbau resistenter Zuckerrübensorten ist und bleibt ein von die wichtigste Werkzeuge, um Nematodenpopulationen zu dezimieren und Nematodenschäden vorzubeugen. 


\section{Chapter 1:}

\section{General introduction}

The European Union (EU) is the world's leading producer of sugar beet, with a production of 128.4 million tons in 2014, covering around $50 \%$ of the global production (Eurostat, 2015). Twenty percent of the global sugar production is derived from sugar beet, while the remaining eighty percent is derived from sugar cane (Eurostat, 2015). The production and the price of sugar beet have recently decreased in the EU due to political decisions related to agricultural subsidies and due to the strong competition against sugar from sugar cane (Bruhns, 2009). Following the major reform of the sugar beet market in 2006, the EU sugar market is regulated by production quotas, minimum beet prices and trade mechanisms (Bruhns, 2009; Belboom \& Léonard, 2012). Conversely, the use of sugar beet for the production of bio-ethanol could give sugar beet production upsurge (Von Blottnitz \& Curran, 2007). The energy balance is very positive, with sugar beets producing 15-16 times more energy than is required to produce it (Řezbová, 2013). The energy output-input ratio for German commercial sugar beet farms is calculated at 15.4 (Reineke et al., 2013). Germany is one of the main European producers of sugar beet with 358 000 hectares (Eurostat, 2015). Due to the high proportion of sugar beet in crop rotations, many leaf and soil-borne pathogens severely limit yield.

Beet cyst nematodes are considered one of the most important pests in sugar beet production worldwide and cause severe damage to sugar beet with yield losses of up to $25 \%$ (Schlang, 1991). It is estimated that the annual yield loss in the EU countries on the world market sugar price level amounts to 90 million Euro (Müller, 1999). Affected plants show stunted growth, decreased chlorophyll content in leaves and symptoms of wilt late in the growing season especially when the plants are exposed to heat and/or water stress conditions (Hillnhütter). Belowground symptoms include the development of compensatory secondary roots, which can result in the typical "bearded" root symptom and an overall beet deformity (Cooke, 1987; Hilnhütter, 2010).

Beet cyst nematodes belong to the family Heteroderidae which is a group of sedentary biotrophic plant-parasitic nematodes characterized by the ability of the female to transform into a tough 
brown cyst which protects the eggs which have been formed within her body (Bohlmann, 2015); see Figure 1 for details on the life cycle. Among the beet cyst nematodes, the sugar beet cyst nematode, Heterodera schachtii and the yellow beet cyst nematode, Heterodera betae, can be distinguished.

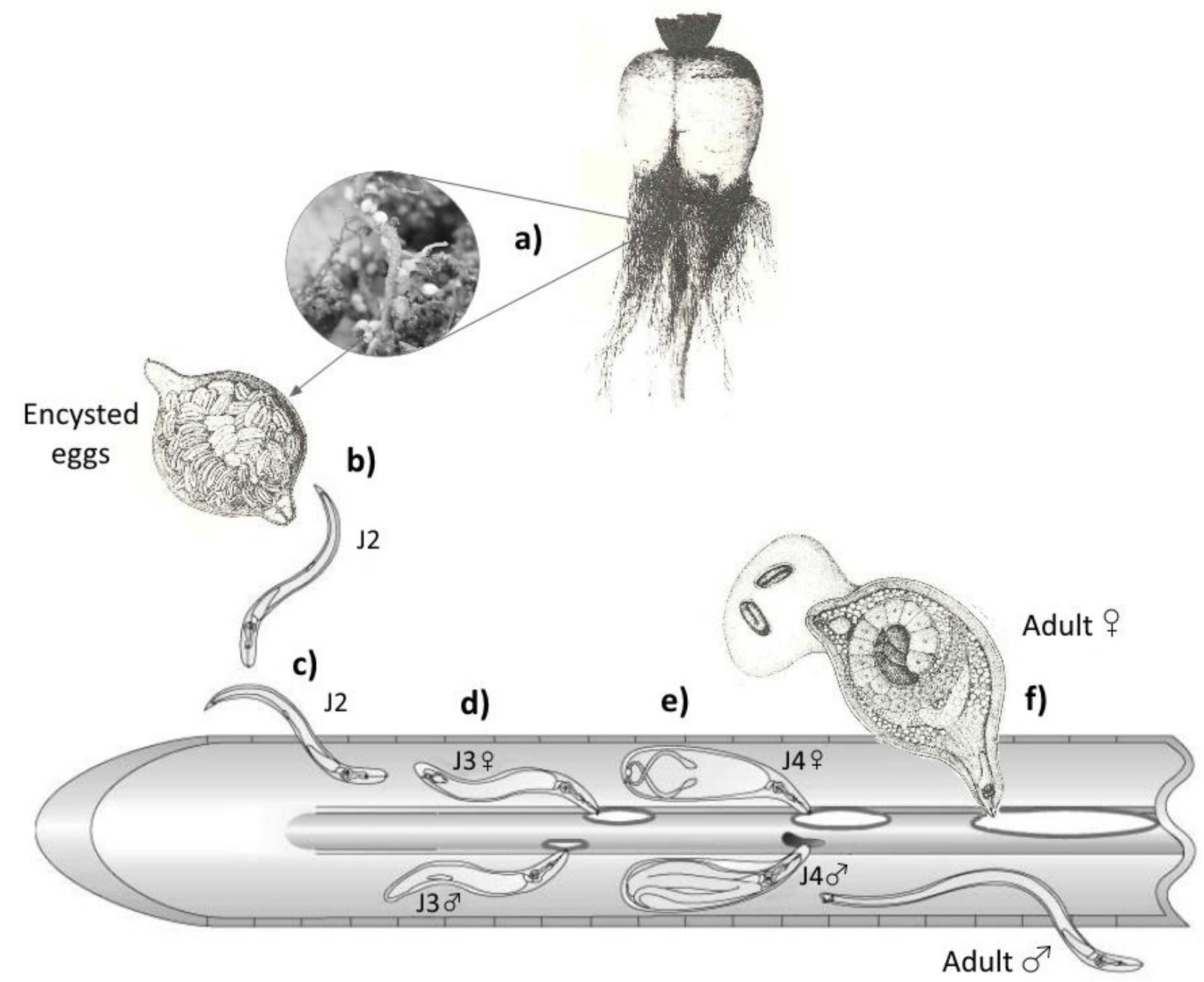

Figure. 1: Life cycle of Heterodera schachtii (a) Sugar beet with roots infested with cysts. (b) Eggs may remain dormant in the soil protected within the tanned cyst for many years. Under favourable conditions, the second-stage juvenile (J2) hatches and migrates towards a host root. (c) The J2 penetrates the root and migrates intracellularly through the cortex towards the vascular cylinder where it initiates formation of a feeding site. Sex is determined towards the end of the J2 stage. (d) A multinucleate feeding site (syncytium) is established by cell wall dissolution. (e) The female enlarges while the motile, vermiform adult male develops within the J4 cuticle. The male does not feed after the J3 stage and its syncytium begins to degrade. (f) The male leaves the root and fertilizes the adult female, which grows to rupture the root surface. Eggs develop within the female body wall, which tans to form the cyst. The life cycle of 
Heterodera betae is similar with the exception that the occurrence of males is not known and reproduction is expected to occur via parthenogenetic mitosis. Adapted from Lilley et al., 2005.

Until now research mostly focused on the biology and control of $H$. schachtii, which has been recognized as a plant pathogen since 1859 when it was associated with stunted and declining sugar beets in Germany (Schacht, 1859). Since then this nematode species was detected in most beet growing areas. Depending on soil type and temperature, the economic threshold of $H$. schachtii ranges from 500 - 1000 second stage juveniles (J2) and eggs $100 \mathrm{ml}^{-1}$ soil (Müller, 1999). The yellow beet cyst nematode, Heterodera betae, was discovered in Dutch beet fields in 1975 and was first considered as a biotype of the clover cyst nematode, $H$. trifolii, able to parasitize sugar beet (Maas \& Heijbroek, 1982). Later on, molecular and morphological characterisation established that $H$. betae was distinct from the $H$. trifolii complex and constituted a true species (Wouts et al., 2001).

The yellow beet cyst nematode is less prevalent but has also been found damaging beet crops (Maas \& Heijbroek, 1982). For H. betae, the damage threshold is estimated at 500 eggs and J2 $100 \mathrm{ml}^{-1}$ soil. The yield will be reduced by about $35 \%$ at 5000 eggs and $\mathrm{J} 2100 \mathrm{ml}^{-1}$ soil (Maas \& Heijbroek, 1982). The host ranges of $H$. schachtii and $H$. betae were shown to be very similar (Gracianne et al., 2014; Maas \& Heijbroek, 1982). Both species have been shown to co-occur in mixed populations in several locations in France, Spain, and Belgium (Gracianne et al., 2014). However, knowledge on how both species interact in co-occurrence is very limited.

Recently, it was hypothesised that $H$. betae derived from $H$. schachtii as a result of speciation by polyploidy and that $H$. betae is better adapted to warmer habitats (Gracianne et al., 2014). Temperature is often the most important environmental factor affecting nematode biology (Trudgill, 1995). Different species have different optimum temperatures for feeding, hatching, reproduction and survival (Neilson \& Boag, 1996), hence their development is strongly influenced by the soil climate (Trudgill, 1995; Trudgill et al., 2005; Kaczmarek et al., 2014).

Climate change has been accelerated by increased anthropogenic greenhouse gas emission in the last century and is associated with rising temperatures around the globe (Solomon et al., 2007). Climate change is expected to cause a mean annual temperature increase in Germany of $2{ }^{\circ} \mathrm{C}$ by 
2050 and up to $4{ }^{\circ} \mathrm{C}$ by 2100 (Jacob \& Podzun, 1997; Werner \& Gerstengarbe, 2007), which will have effects on both crop and pathogen development (Weigel, 2005; Racca et al., 2015). Rising average temperatures may lead to changes in crop phenology, but also in the incidence of pathogens (Racca et al., 2015). Global warming may either increase or decrease crop production in the future, depending on local conditions (Rosenzweig et al., 2002). For example, climate impact studies predict that sugar beet yield will increase because of the positive effects of warmer springs and increased $\mathrm{CO}_{2}$ concentration at northern temperate latitudes where the length of the growing season currently limits production (Donatelli et al., 2002; Qi et al., 2005). Sowing may then occur earlier because of warmer weather conditions (Qi et al., 2005). In Mediterranean-type environments, where high summer temperatures and water stress already limit crop production, simulations with increased temperatures have shown either a negative (Rosenzweig et al., 2002), positive (Bindi \& Olesen, 2011) or no impact (Donatelli et al., 2002). Predicted global warming may shorten the generation time of nematodes which may increase the population density and dominance of species better adapted to higher temperatures.

The interaction between the beet cyst nematodes and sugar beet remains relevant as this pest can lead to serious yield losses. Understanding these interactions and the climatic factors influencing them is important in order to adapt management strategies. The work presented here is part of the research framework "KLIFF - climate impact and adaptation research in Lower Saxony", funded by the Ministry for Science and Culture of Lower Saxony. It is one of the first projects in Germany to investigate and assess potential effects of climate change on crop production at a regional scale. The aim of this thesis is to expand current knowledge on the influence of temperature on interactions between sugar beet cyst nematode ( $H$. schachtii), yellow beet cyst nematode ( $\mathrm{H}$. betae) and the sugar beet plants. Experiments were conducted in the laboratory, in climate chambers and outdoors in heated containers. In the following chapters, answers to several research questions will be presented.

Chapter $\mathbf{1}$ is an introductory chapter, highlighting the importance of sugar beet production. Beet cyst nematodes are discussed as part of major constraints to sugar beet production. The two different beet cyst nematode species, $H$. schachtii and $H$. betae, are introduced, describing their biology and their impact on sugar beet production. Potential influences of rising temperatures on nematode development are described. 
In chapter 2, hatching experiments were set up to study the influence of temperature on the hatching behaviour of the two beet cyst nematode species, $H$. schachtii and $H$. betae. Differences in hatch between the beet cyst nematode species were assessed at constant temperatures in incubators as well as under simulated temperature conditions set to be $4{ }^{\circ} \mathrm{C}$ higher than the standard temperature regime.

In chapter 3, the effect of increased soil temperatures on the interaction between sugar beet cultivars and $H$. schachtii was investigated. An electric heating mat system was established outdoors to increase the soil temperature by $2.8{ }^{\circ} \mathrm{C}$ in heated compared to unheated soil containers. The effect of experimental soil warming on $H$. schachtii population development and sugar beet performance was assessed for sugar beet cultivars that were susceptible, tolerant or resistant to $H$. schachtii.

In chapter 4, it was investigated how the beet cyst nematode species, H. schachtii and H. betae interact and whether temperature affects the interspecific competition between both species. In two climate chambers differing in temperature by $4{ }^{\circ} \mathrm{C}$, sugar beet seedlings were challenged with Heterodera schachtil, $H$. betae, or a mixture of both species. To determine the relative abundance of both species in mixed populations, quantitative PCR systems were developed for both species based on sequence differences in the cytochrome oxidase subunit 1 gene. The aim was to determine if higher temperature regimes will induce shifts in the relative abundance of both beet nematode species.

In chapter 5, the results presented in the previous chapters are placed in a broader context. The implications of higher temperature regimes on the future impact of beet cyst nematodes and their management are discussed. 


\section{References}

Belboom, S. \& Léonard, A. (2012). Improving bioethanol production by increasing sugar beet crop yield. Plant Sciences Reviews 2011, 49-58.

Bindi, M. \& Olesen, J. E. (2011). The responses of agriculture in Europe to climate change. Regional Environmental Change 11, 151-158.

Bohlmann, H. (2015). Introductory chapter on the basic biology of cyst nematodes. Advances in Botanical Research 73, 33-59.

Bruhns, J. (2009). The reform of the EU sugar regime and its effects on the industry. Sugar Journal 71, 13-16.

Cooke, D. (1987). Beet cyst nematode (Heterodera schachtii Schmidt) and its control on sugar beet. Agricultural Zoology Reviews.

Donatelli, M., Tubiello, F., Peruch, U. \& Rosenzweig, C. (2002). Impacts of climate change and elevated $\mathrm{CO}_{2}$ on sugar beet production in Northern and Central Italy. Italian Journal of Agronomy 6, 133-142.

Eurostat (2015). Agricultural production-crops. Link: http://ec.europa.eu/eurostat/statisticsexplained/index.php/Agricultural_production_-_crops

Gracianne, C., Petit, E., Arnaud, J.-F., Porte, C., Renault, L., Fouville, D., Rouaux, C. \& Fournet, S. (2014). Spatial distribution and basic ecology of Heterodera schachtii and H. betae wild populations developing on sea beet, Beta vulgaris ssp. maritima. Nematology 16, 797-805.

Hillnhütter, C. (2010) Non-destructive evaluation of complex interactions between Heterodera schachtii and Rhizoctonia solani on sugar beet as affected by cultivar resistance. $\mathrm{PhD}$ thesis

Jacob, D. \& Podzun, R. (1997). Sensitivity studies with the regional climate model REMO. Meteorology and Atmospheric Physics 63, 119-129.

Kaczmarek, A., Mackenzie, K., Kettle, H. \& Blok, V. (2014). Influence of soil temperature on Globodera rostochiensis and Globodera pallida. Phytopathologia Mediterranea 53, 396405.

Lilley, C. J., Atkinson, H. J. \& Urwin, P. E. (2005). Molecular aspects of cyst nematodes. Molecular Plant Pathology 6, 577-588.

Maas, P. W. T. \& Heijbroek, W. (1982). Biology and pathogenicity of the yellow beet cyst nematode; a host race of Heterodera trifolii on sugar beet in the Netherlands. Nematologica 28, 77-93.

Müller, J. (1999). The economic importance of Heterodera schachtii in Europe. Helminthologia $36,205-213$.

Neilson, R. \& Boag, B. (1996). The predicted impact of possible climatic change on virus-vector nematodes in Great Britain. European Journal of Plant Pathology 102, 193-199. 
Qi, A., Kenter, C., Hoffmann, C. \& Jaggard, K. (2005). The Broom's Barn sugar beet growth model and its adaptation to soils with varied available water content. European Journal of Agronomy 23, 108-122.

Racca, P., Kakau, J., Kleinhenz, B. \& Kuhn, C. (2015). Impact of climate change on the phenological development of winter wheat, sugar beet and winter oilseed rape in Lower Saxony, Germany. Journal of Plant Diseases and Protection 122, 16-27.

Reineke, H., Stockfisch, N. \& Märländer, B. (2013). Analysing the energy balances of sugar beet cultivation in commercial farms in Germany. European Journal of Agronomy 45, 27-38.

Řezbová, H. (2013). Sugar beet production in the European Union and their future trends. AGRIS On-line Papers in Economics and Informatics 5, 165-178.

Rosenzweig, C., Tubiello, F., Goldberg, R., Mills, E. \& Bloomfield, J. (2002). Increased crop damage in the US from excess precipitation under climate change. Global Environmental Change 12, 197-202.

Schacht, H. (1859). Über einige Feinde und Krankheiten der Zuckerrübe. Zeitschrift des Vereins für die Rübenzuckerindustrie im Zollverein 9, 239-250.

Schlang, J. (1991). Anbau resistenter Zwischenfrüchte zur biologischen Bekämpfung des Rübenzystennematoden. Zuckerrübe 40, 476-488.

Solomon, S., Qin, D., Manning, M., Chen, Z., Marquis, M., Averyt, K., Tignor, M. \& Miller, H. (2007). IPCC, 2007: Summary for Policymakers, Climate Change 2007: The Physical Science Basis. Contribution of Working Group I to the Fourth Assessment Report of the Intergovernmental Panel on Climate Change. Cambridge University Press, New York.

Trudgill, D. (1995). An assessment of the relevance of thermal time relationships to nematology. Fundamental and Applied Nematology 18, 407-417.

Trudgill, D., Honek, A., Li, D. \& Straalen, N. (2005). Thermal time-concepts and utility. Annals of Applied Biology 146, 1-14.

Von Blottnitz, H. \& Curran, M. A. (2007). A review of assessments conducted on bio-ethanol as a transportation fuel from a net energy, greenhouse gas, and environmental life cycle perspective. Journal of cleaner production 15, 607-619.

Weigel, H. (2005). Healthy plants in the future: how does climate change affect crop production? Gesunde Pflanzen 57, 6-17.

Werner, P. C. \& Gerstengarbe, F.-W. (2007). Welche Klimaänderungen sind in Deutschland zu erwarten. Der Klimawandel-Einblicke, Rückblicke und Ausblicke. Potsdam-Institut für Klimafolgenforschung und Humboldt-Universität zu Berlin, Berlin/Potsdam, 56-59. 


\title{
Chapter 2:
}

\section{Effect of temperature on the hatch of two German populations of the beet cyst nematodes, Heterodera schachtii and Heterodera betae}

\author{
Bart AB Vandenbossche ${ }^{1,2}$, Björn Niere $^{1}$ and Stefan Vidal ${ }^{2}$ \\ ${ }^{1}$ Julius Kühn-Institut, Federal Research Centre for Cultivated Plants, Institute for National and \\ International Plant Health, Messeweg 11/12, 38104 Braunschweig, Germany \\ ${ }^{2}$ Georg-August-University Göttingen, Department of Crop Sciences, Section Agricultural \\ Entomology, Grisebachstrasse 6, 37077 Göttingen, Germany
}

Corresponding author, e-mail: bavdenbo.vandenbossche@gmail.com

*Chapter published in Journal of Plant Diseases and Protection.

Vandenbossche B.A.B., Niere B., Vidal S. (2015). Effect of temperature on the hatch of two German populations of the beet cyst nematodes, Heterodera schachtii and Heterodera betae. Journal of Plant Diseases and Protection, 122 (5/6), 250-254. 


\begin{abstract}
Beet cyst nematodes, Heterodera schachtii and H. betae, cause damage to sugar beet production and could become even more important with increasing soil temperatures. In northern Germany, temperatures are expected to rise by $4{ }^{\circ} \mathrm{C}$ by 2100 . In this study, we investigated the hatch of two beet cyst nematode species at constant temperatures as well as simulated temperature conditions set to be $4{ }^{\circ} \mathrm{C}$ higher than the standard temperature regime. The effect of different constant temperatures on the emergence of second-stage juveniles of $H$. schachtii and $H$. betae was investigated using six incubators set at $5,10,15,20,25$ and $30{ }^{\circ} \mathrm{C}$ for a period of 6 weeks. In a second experiment, the effect of increased and standard temperature regimes on the emergence of second-stage juveniles of $H$. schachtii and $H$. betae was investigated in climate chambers for 12 weeks. The highest cumulative hatching rates for $H$. schachtii were observed at temperatures between 15 and $30{ }^{\circ} \mathrm{C}$ and for $H$. betae between 20 and $30{ }^{\circ} \mathrm{C}$, suggesting that this can be considered as the optimal temperature range for hatch. The emergence of juveniles of both beet cyst nematode species started at $5{ }^{\circ} \mathrm{C}$, but cumulative hatch percentages were less than $1 \%$. Differences in final cumulative hatching rate of $H$. schachtii and $H$. betae between the increased and standard temperature regime were not significant.
\end{abstract}

Keywords: Global warming, juvenile emergence, life cycle, thermal time 


\section{Introduction}

The beet cyst nematodes, Heterodera schachtii and $H$. betae are regarded as the most important pests in sugar beet production systems worldwide leading to yield losses of up to 25\% (Amiri et al. 2002).

Temperature is a major factor regulating the development of beet cyst nematodes (Griffin 1981a, Trudgill 1995). Predicted rising temperatures through global warming may result in a faster nematode development, shorter life cycle with the potential of more generations per growing season (Curi \& Zmoray 1966, Griffin 1981b, Kakaire et al. 2012). Furthermore, an earlier hatch of eggs and emergence of juveniles from the cyst could result in a population build-up at an earlier developmental stage of the sugar beet plants when they are most vulnerable to nematode damage (Griffin 1981a, Olthof 1983, Wrather \& Anand 1988). Heterodera schachtii, the sugar beet cyst nematode, is considered the most important nematode pests of sugar beet and is present in most sugar-beet growing areas (Cooke 1991). The yellow beet cyst nematode, H. betae, is less prevalent but is also reported to cause damage to beet crops (Wouts et al. 2001). Limited information is available on the influence of temperature on the hatching of eggs and emergence of second-stage juveniles of $H$. betae compared with $H$. schachtii. Current knowledge of hatching behaviour of $H$. betae is based on research conducted in 1982 on a special race of $H$. trifolii from the Netherlands (Maas \& Heijbroek 1982, Steele et al. 1982), later identified as H. betae (Wouts et al. 2001). Previous studies suggested that $H$. betae is more adapted to warmer conditions (Maas \& Heijbroek 1982). According to model predictions, temperature in northern Germany is expected to rise by $4{ }^{\circ} \mathrm{C}$ by 2100 (Jacob \& Podzun 1997, Werner \& Gerstengarbe 2007). It is therefore of pivotal interest to understand the role of increasing temperatures on hatching behaviour of these nematode species.

The research objectives of this study were to investigate i) differences in hatch in water of the beet cyst nematode species $H$. schachtii and $H$. betae at constant temperatures, and ii) hatch of both beet cyst nematode species under fluctuating standard- and $4{ }^{\circ} \mathrm{C}$ increased temperature regimes. 


\section{Materials and Methods}

\subsection{Nematodes}

The H. schachtii population used in this study was originally isolated from a sugar beet field in Germany and is used in standard resistance tests (Müller \& Rumpenhorst 2000). The H. betae population was originally isolated from a sugar beet field in Goch, North Rhine-Westphalia, Germany. Pure cultures of these populations were maintained on oilseed rape cultivar Ladoga at the Julius Kühn-Institut, Braunschweig. Newly-formed cysts were extracted from the soil using a MEKU high-pressure elutriator (MEKU, Wennigsen/Deister, DE) with $40 \mathrm{~s}$ high pressure $/ 5 \mathrm{~s}$ pause settings. Separation of cysts from soil debris on the paper filter and cysts counting were carried out under a stereoscopic binocular (Leica MZ8, Wetzlar, Germany).

\subsection{Experimental design}

\section{Experiment 1 - Effect of temperature on spontaneous hatch in water}

The effect of different constant temperatures on the emergence of second-stage juveniles of $H$. schachtii and $H$. betae was investigated using six incubators (Heraeus BK 5060 EL, Langenselbold, Germany) set at 5, 10, 15, 20, 25 and $30^{\circ} \mathrm{C}$. Temperature within each incubator was recorded every hour with data loggers (Testo T175 T3, Lenzkirch, Germany). Five replicates per treatment were used, with each replicate consisting of a $2 \mathrm{ml}$ Eppendorf tube with five newlyformed cysts in $1 \mathrm{ml}$ tap water. The closed tubes were arranged in boxes and placed into the six corresponding incubators for a total duration of six weeks.

\section{Experiment 2 - Effect of temperature on hatch under stimulation with the hatching agent $\mathrm{ZnCl}_{2}$}

The effect of a standard and an increased temperature regime on the emergence of second-stage juveniles of $H$. schachtii and $H$. betae was investigated in climate chambers for 12 weeks. The standard climate regime was set for the first two weeks at $18{ }^{\circ} \mathrm{C}$ day $/ 8{ }^{\circ} \mathrm{C}$ night and the following 10 weeks at $20{ }^{\circ} \mathrm{C}$ day $/ 1{ }^{\circ} \mathrm{C}$ night. In the increased temperature regime temperature was set $4{ }^{\circ} \mathrm{C}$ higher than in the standard temperature: the first two weeks temperature was set at $22{ }^{\circ} \mathrm{C}$ day/12 ${ }^{\circ} \mathrm{C}$ night and the following 10 weeks at $24{ }^{\circ} \mathrm{C}$ day/15 ${ }^{\circ} \mathrm{C}$ night. Six replicates per treatment were used, with each replicate consisting of a $2.0 \mathrm{ml}$ Eppendorf tube with five newly-formed cysts in 
$1.0 \mathrm{ml}$ of a $3 \mathrm{mM} \mathrm{ZnCl}_{2}$-solution. The closed tubes were arranged in boxes and placed at the standard or increase temperature regimes in the corresponding climate chambers.

\subsection{Data collection and analysis}

Data on the emergence of juveniles was recorded weekly for the duration of the experiments. From each tube, hatched second stage juveniles were removed and counted under a stereo microscope (Leica MZ8; Wetzlar, Germany). The tubes with cysts were immediately replenished with either $1.0 \mathrm{ml}$ tap water (Experiment 1) or $1.0 \mathrm{ml} 3 \mathrm{mM} \mathrm{ZnCl}_{2}$-solution (Experiment 2) per tube and returned to their respective incubator. At the end of the experiment, all cysts were crushed to count the number of eggs and juveniles remaining inside and the total number of eggs and juveniles (hatched plus unhatched) per replicate were determined. Data are presented as cumulative hatching rates of viable juveniles at each counting date. Data were checked for normality using the capability procedure test in SAS software Version 9.3 (SAS Institute Inc., Cary, NC, USA). Proc Mixed procedures with repeated measures were used in SAS to check for the effect temperature and nematode species (independent variables) on the number of hatched juveniles (dependent variable). Tukey multiple range tests were performed to separate means at $5 \%(P \leq 0.05)$ confidence level. Non-transformed means are presented in figures for clarity.

\section{Results}

\section{Experiment 1 - Effect of temperature on spontaneous hatch in water}

Cumulative hatching rates of H. schachtii (Fig. 1) and H. betae (Fig. 2) populations were recorded over 6 weeks at constant temperatures of $5^{\circ} \mathrm{C}, 10^{\circ} \mathrm{C}, 15^{\circ} \mathrm{C}, 20{ }^{\circ} \mathrm{C}, 25^{\circ} \mathrm{C}$ and $30{ }^{\circ} \mathrm{C}$. At $5{ }^{\circ} \mathrm{C}$, juveniles of both beet cyst nematodes were only detected after week 3 and week 4 . Only up to 3 juveniles emerged per replicate from the incubated cysts at temperatures of $5{ }^{\circ} \mathrm{C}$. Cumulative hatching rates ranged from 0 to $0.18 \%$ for $H$. schachtii and from 0 to $0.22 \%$ for $H$. betae. 


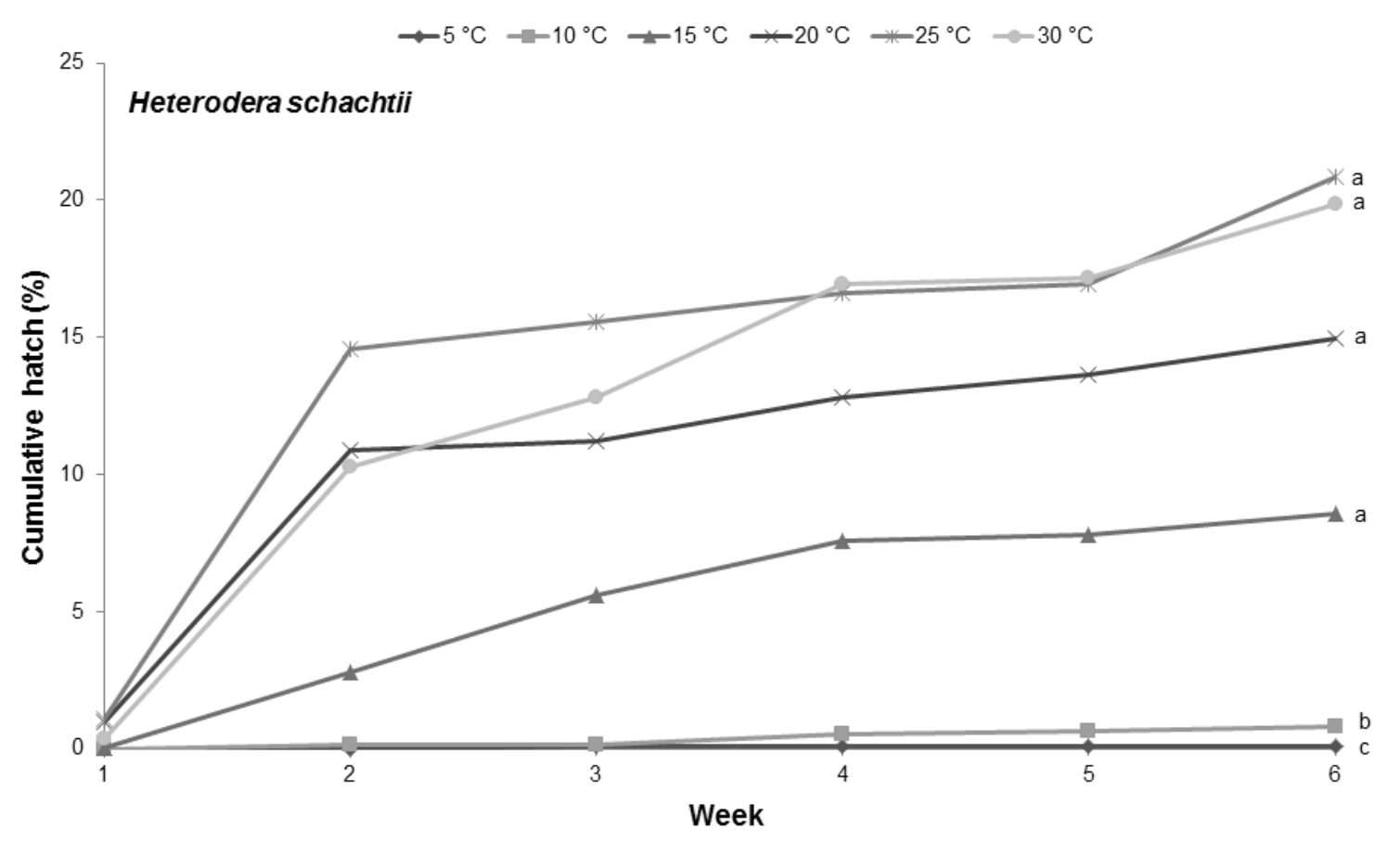

Fig. 1: Cumulative hatch of second-stage juveniles from five cysts of Heterodera schachtii in water at different temperatures $\left({ }^{\circ} \mathrm{C}\right)$ over six weeks. Each point on the graph is a mean of five replicates. Data followed by the same letter are not significantly different at $P \leq 0.05$ with Tukey multiple range test.

At $10{ }^{\circ} \mathrm{C}$, no juveniles of both species emerged after one week of incubation. Similarly, low numbers of juveniles of $H$. betae emerged from the cyst with cumulative hatching rates from 0 to $0.2 \%$, which were not significantly different from those at $5{ }^{\circ} \mathrm{C}(P=1.00)$. Emergence of $H$. betae juveniles at $10{ }^{\circ} \mathrm{C}$ was not significantly different than at $5{ }^{\circ} \mathrm{C}$, with cumulative hatching ranging from 0.3 to $2 \%$. At $25{ }^{\circ} \mathrm{C}$, final cumulative hatching rates of $20.8 \%$ for $\mathrm{H}$. schachtii and 9.7\% for $H$. betae were detected. For $H$. schachtii there was no significant difference in hatching rate between 15 and $30^{\circ} \mathrm{C}$.

The hatching rate of $H$. betae was significantly higher at $25^{\circ} \mathrm{C}$ than at $5{ }^{\circ} \mathrm{C}(P=0.006), 10{ }^{\circ} \mathrm{C}(P$ $=0.006)$ and $15{ }^{\circ} \mathrm{C}(P=0.026)$. There was no significant difference in final hatching rates between 20 and $30{ }^{\circ} \mathrm{C}$. Heterodera betae hatched more rapidly than $H$. schachtii, and after the first week hatching rates of around 50\% of the final cumulative hatching rate were reached at temperatures of $20-25{ }^{\circ} \mathrm{C}$. A high proportion of $\mathrm{H}$. schachtii juveniles emerged already in the second week of incubation. 


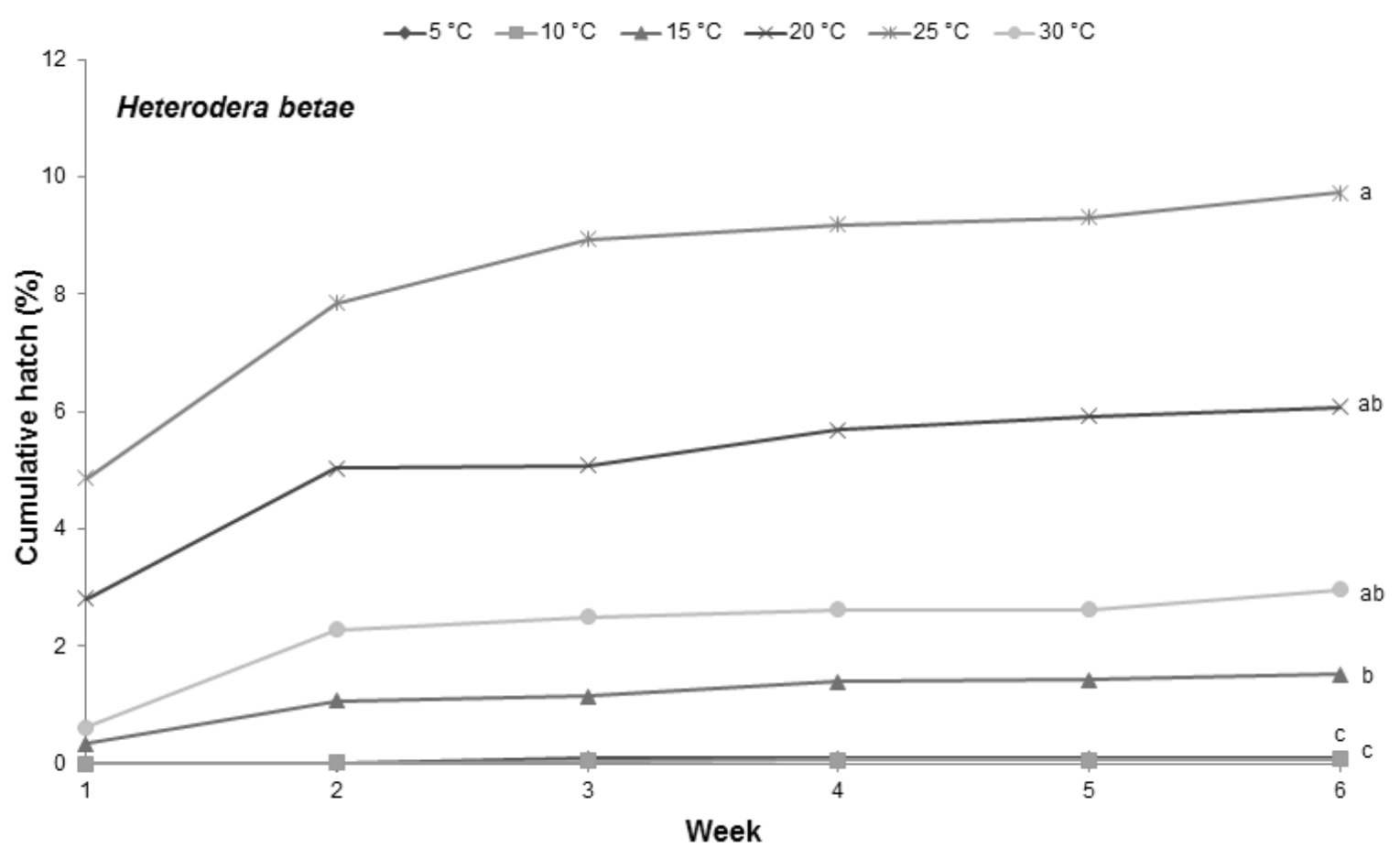

Fig. 2: Cumulative hatch of second-stage juveniles from five cysts of Heterodera betae in water at different temperatures $\left({ }^{\circ} \mathrm{C}\right)$ over six weeks. Each point on the graph is a mean of five replicates. Data followed by the same letter are not significantly different at $P \leq 0.05$ with Tukey multiple range test.

\section{Experiment 2 - Effect of temperature on hatch under stimulation with the hatching agent $\mathrm{ZnCl}_{2}$}

Percentages of cumulative hatched juveniles of $H$. schachtii and $H$. betae populations over 12 weeks at the standard temperature regime (Ts) and at the increased temperature regime (Ti) are shown in Fig.3. Cumulative hatch was higher for $H$. schachtii than for $H$. betae in both standard $(P=0.001)$ and increased temperature regimes $(P=0.043)$. About $92 \%$ of second-stage juveniles of $H$. schachtii emerged from the cysts. No difference of temperature treatment on the total hatch percentage was recorded for $H$. schachtii $(P=0.99)$. During the first two weeks, cumulative hatch percentages below 5\% were recorded. After four weeks, 57\% (Ts) and 60\% (Ti) of $H$. schachtii juveniles emerged. About $77.6 \%$ juveniles of $H$. betae emerged at the increased temperature regime, which is more than in the standard temperature regime (69.6\%); however, these differences were not statistically different $(P=0.42)$. After the first five weeks, more than 
$50 \%$ of juveniles emerged. The cumulative hatching curves indicate a delayed hatch of around 3 weeks for all treatments, except for $H$. betae at increased temperature regime. After the second week, the cumulative hatching rate of $H$. betae was significantly higher $(P=0.0002)$ in the increased temperature regime (24\%), compared with the standard temperature regime $(5.8 \%)$.

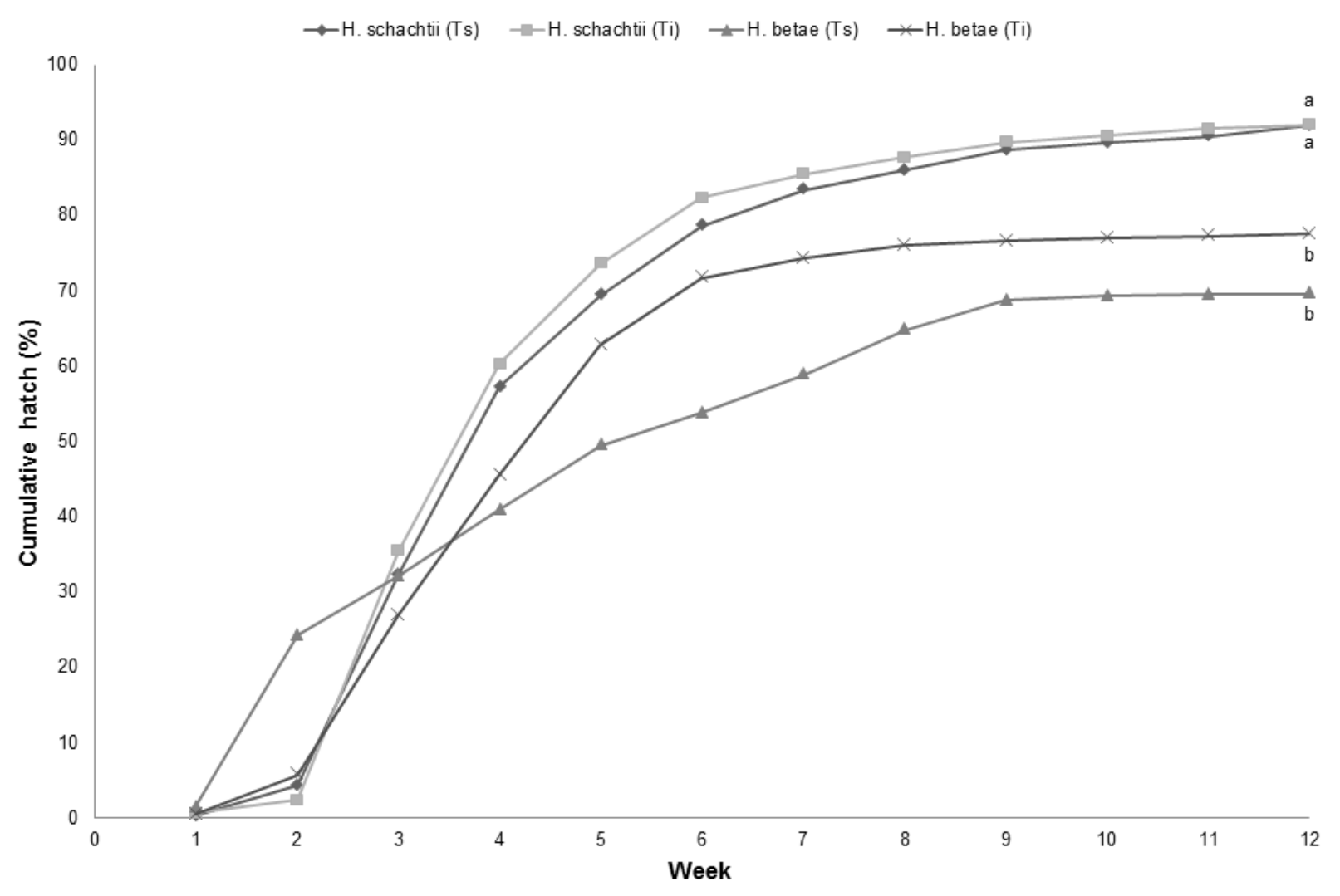

Fig. 3: Cumulative hatch of second-stage juveniles from five cysts of Heterodera schachtii and $H$. betae in $1.0 \mathrm{ml} 3 \mathrm{mM} \mathrm{ZnCl}$-solution at a standard and an increased temperature regime over twelve weeks. Each point on the graph is a mean of six replicates. Data followed by the same letter are not significantly different at $P \leq 0.05$ with Tukey multiple range test. Capital letters were used to show differences between weeks inside a treatment. Small letters were used to show differences between different treatments.

\section{Discussion}

The optimal temperatures for hatch were different for both beet cyst nematode species. The optimum temperature range is the temperature range within which most nematode development (e.g. hatching) occurs. With H. schachtii we found that there was a broader temperature range 
over which similar cumulative hatching rates occurred in comparison with $H$. betae. The optimal temperature range for hatch of $H$. schachtii was found to be between 15 and $30{ }^{\circ} \mathrm{C}$ and for $H$. betae between 20 and $30{ }^{\circ} \mathrm{C}$. Hatch of $\mathrm{H}$. schachtii at $15^{\circ} \mathrm{C}$ and $20{ }^{\circ} \mathrm{C}$ was, although not significantly, lower, than at $25^{\circ} \mathrm{C}$ and $30{ }^{\circ} \mathrm{C}$, suggesting that 15 till $20{ }^{\circ} \mathrm{C}$ is only a sub-optimal temperature range for hatch of the studied $H$. schachtii population. Previous comparative hatch tests reported $25{ }^{\circ} \mathrm{C}$ and $30{ }^{\circ} \mathrm{C}$ as optimal temperatures for hatch of both beet cyst nematode species (Maas \& Heijbroek 1982).

Emergence of second-stage juveniles of $H$. schachtii began at a base temperature $5{ }^{\circ} \mathrm{C}$; however, in very low percentages. This finding from our experiments concurs with results of hatch tests as reported by Kakaire et al (2012). The base temperature $(\mathrm{Tb})$ is the temperature below which no measurable development occurs. By contrast, other studies investigating $H$. schachtii hatch reported higher base temperatures of $6.3{ }^{\circ} \mathrm{C}$ (Griffin 1988), $8{ }^{\circ} \mathrm{C}$ (Caswell \& Thomason 1991) and $10{ }^{\circ} \mathrm{C}$ (Maas \& Heijbroek 1982). These variations in $\mathrm{Tb}$ values could be due to several factors such as variations in their adaptability to temperature, as well on the methodology and accuracy of assessment (Kakaire et al. 2012). Emergence of second-stage juveniles of H. betae also began at $5{ }^{\circ} \mathrm{C}$; however, similar to $H$. schachtii also in very low percentages. These results are in contrast to previous hatch studies where hatch of $H$. betae populations from the Netherlands began only at $15^{\circ} \mathrm{C}$ (Maas \& Heijbroek 1982, Steele et al. 1982).

Cumulative hatching rates recorded here for $H$. schachtii in water are in accordance with the mean hatch percentage of $H$. schachtii out of 44 tests in distilled water of $13 \%$ after 3 weeks at 25 ${ }^{\circ} \mathrm{C}$ (Clarke \& Shepherd 1964) and close to hatching rates reported for both species in tap water (Maas \& Heijbroek 1982). In contrast, other hatch studies reported that up to $50 \%$ of the secondstage juveniles of $H$. schachtii hatch from eggs spontaneously within the first week in water (Clarke \& Perry 1977, Zheng \& Ferris 1991).

For both beet cyst nematode species, no significant differences were found in the final cumulative hatch percentages when comparing the standard and the increased temperature regimes. Cumulative hatching percentages reached about $90 \%$ for $H$. schachtii in both temperature regimes. Final numbers of $H$. betae juvenile emergence were lower than those for $H$. schachtii, which is in accordance with previous studies (Maas \& Heijbroek 1982, Steele et al. 1982). Rising soil temperatures may exert a selection pressure among beet cyst nematodes to adapt to changes in temperature (Kakaire et al. 2012). The direct effect of temperature on the development and 
population growth of nematodes also explains the importance of thermal adaptation; the abilities to acclimatize, orient towards optimal temperatures and anticipate on the occurrence of extreme low and high temperatures are profoundly selected behaviours (Yeates et al. 2004). For example, the potato cyst nematodes, Globodera pallida and G. rostochiensis differ in their temperature responses. Globodera pallida generally hatches and reproduces at lower temperatures than $G$. rostochiensis, and G. rostochiensis is more competitive than G. pallida at temperatures above 20 ${ }^{\circ} \mathrm{C}$ (Franco 1979). We found that $H$. schachtii had a broader optimal temperature range and a higher cumulative hatching rate at higher temperatures than $H$. betae. Increasing temperatures are thus likely to cause higher levels of hatching of beet cyst nematodes, potentially resulting in higher infestation levels. Although increasing temperatures could have a positive effect on sugar beet yield due to faster phenological development, this effect can be mitigated due to the earlier incidence of beet cyst nematodes (Racca et al., 2015). Temperature has also been reported to influence the pathogenicity of nematodes so that the damage threshold of $H$. schachtii on sugar beet grown in Germany declined from 20 eggs $\mathrm{g}^{-1}$ soil in April to $2.5 \mathrm{eggs} \mathrm{g}^{-1}$ soil in May as a result of an increase in soil temperature at planting (Steudel \& Thielemann, 1970). A recent study on the spatial distribution of both beet cyst nematodes on sea beet, Beta vulgaris spp. maritima reported that $H$. schachtii mainly occurred in the colder environments of northern Europe, whereas $H$. betae was preferentially distributed in the warmer environments of southern Europe (Gracianne et al., 2014).

This study provides insight on the influence of temperature on the comparative hatch among beet cyst nematode species from Germany; however, these results cannot be directly extrapolated to determine the hatching behaviour under field conditions. Further studies investigating the effect

of temperature on hatching rates, and the life cycle of both beet cyst nematode species during growing season in the field are necessary to better predict the influence of increasing temperatures on beet cyst nematode population dynamics.

\section{Acknowledgements}

This work was financially supported by the Ministry for Science and Culture of Lower Saxony, Germany, within the research network "KLIFF" - climate impact in Lower Saxony. 


\section{References}

Amiri S, Subbotin SA \& Moens M, 2002. Identification of the beet cyst nematode Heterodera schachtii by PCR. Eur J Pl Pathol 108, 497-506.

Caswell EP \& Thomason IJ, 1991. A model of egg production by Heterodera schachtii (Nematoda: Heteroderidae). Can J Zool 69, 2085-2088.

Clarke AJ \& Shepherd AM, 1964. Synthetic hatching agents for Heterodera schachtii Schm. and their mode of action. Nematologica 10, $431-453$.

Clarke AJ \& Perry RN, 1977. Hatching of cyst-nematodes. Nematologica 23, 350-363.

Cooke DA, 1991. The effect of beet cyst nematode, Heterodera schachtii, on the yield of sugar beet in organic soils. Ann Appl Biol 118, 153-160.

Curi J \& Zmoray I, 1966. Beziehung klimatischer Faktoren zur Entwicklungsdauer von Heterodera schachtii in der Slowakei (CSSR). Helminthologia 7, 49-63.

Franco J, 1979. Effect of temperature on hatching and multiplication of potato cyst-nematodes. Nematologica 25, 237-244.

Gracianne C, Petit E, Arnaud J-F, Porte C, Renault L, Fouville D, Rouaux C \& Fournet S 2014. Spatial distribution and basic ecology of Heterodera schachtii and $H$. betae wild populations developing on sea beet, Beta vulgaris ssp. maritima. Nematology 16, 797-805.

Griffin G, 1981a. The relationship of plant age, soil temperature, and population density of Heterodera schachtii on the growth of sugarbeet. J Nematol13, 184.

Griffin G, 1981b. The interaction of Heterodera schachtii and Ditylenchus dipsaci on sugarbeet. J Nematol 13, 441-441.

Griffin G, 1988. Factors affecting the biology and pathogenicity of Heterodera schachtii on sugarbeet. J Nematol 20, 396-404.

Jacob D \& Podzun R, 1997. Sensitivity studies with the regional climate model REMO. Meteorl Atmos Phys 63, 119-129. 
Kakaire S, Grove I \& Haydock P, 2012. Effect of temperature on the life cycle of Heterodera schachtii infecting oilseed rape (Brassica napus L.). Nematology 14, 855-867.

Maas PWT \& Heijbroek W, 1982. Biology and pathogenicity of the yellow beet cyst nematode; a host race of Heterodera trifolii on sugar beet in the Netherlands. Nematologica 28, 77-93.

Müller J \& Rumpenhorst H, 2000. Die Prüfung von Pflanzen auf ihre Widerstandsfähigkeit gegen Schadorganismen in der Biologischen Bundesanstalt. Teil 1 Prüfung von Kulturpflanzen auf Resistenz gegen pflanzenparasitäre Nematoden. Mitt Biol Bundesanst Land-Forstwirtsch Berlin-Dahlem 372, 38.

Olthof T, 1983. Effect of plant age and transplanting damage on sugarbeets infected by Heterodera schachtii. J Nematol15, 555-559.

Racca P, Kakau J, Kleinhenz B \& Kuhn C 2015. Impact of climate change on the phenological development of winter wheat, sugar beet and winter oilseed rape in Lower Saxony, Germany. J P1 Dis Protect 122, 16-27.

Steele A, Toxopeus H \& Heijbroek W, 1982. A comparison of the hatching of juveniles from cysts of Heterodera schachtii and H. trifolii. J Nematol 14, 588.

Steudel W \& Thielemann R 1970. Weitere Untersuchungen zur Frage der Empfindlichkeit von Zuckerrüben gegen den Rübennematoden (Heterodera schachtii Schmidt). Zucker 23, 106109.

Trudgill D, 1995. An assessment of the relevance of thermal time relationships to nematology. Fund Appl Nematol 18, 407-417.

Werner PC \& Gerstengarbe FW, 2007. Welche Klimaänderungen sind in Deutschland zu erwarten? In: Endlicher W and Gerstengarbe FW (Ed.) 2007: Der Klimawandel-Einblicke, Rückblicke und Ausblicke. Potsdam-Institut für Klimafolgenforschung und HumboldtUniversität zu Berlin, Berlin/Potsdam, 56-59.

Wouts WM, Rumpenhorst HJ \& Sturhan D, 2001. Heterodera betae sp n., the yellow beet cyst nematode (Nematoda : Heteroderidae). Russ J Nematol 9, 33-42.

Wrather J \& Anand S, 1988. Relationship between time of infection with Heterodera glycines and soybean yield. J Nematol 20, 439. 
Yeates GW, Gaugler R \& Bilgrami A, 2004. Ecological and behavioural adaptations. In: Gaugler R \& Bilgrami AL (Eds.) 2004: Nematode Behaviour, 1-24. CAB International.

Zheng L \& Ferris H, 1991. Four types of dormancy exhibited by eggs of Heterodera schachtii. Rev Nématol 14, 419-426. 


\title{
Chapter 3:
}

\section{Influence of experimental soil warming on population density of Heterodera schachtii and the performance of different sugar beet cultivars}

\author{
Bart AB Vandenbossche ${ }^{1,2}$, Björn Niere ${ }^{1}$ and Stefan Vidal, ${ }^{2}$ \\ ${ }^{1}$ Julius Kühn-Institut, Federal Research Centre for Cultivated Plants, Institute for National and \\ International Plant Health, Messeweg 11/12, 38104 Braunschweig, Germany \\ ${ }^{2}$ Georg-August-University Göttingen, Department of Crop Sciences, Section Agricultural \\ Entomology, Grisebachstrasse 6, 37077 Göttingen, Germany
}

Corresponding author, e-mail: bavdenbo.vandenbossche@gmail.com

*Chapter in preparation for submission to a peer-reviewed journal

Vandenbossche, B.A.B., Niere, B. \& Vidal, S. (2016). Influence of experimental soil warming on population density of Heterodera schachtii and the performance of different sugar beet cultivars. 


\begin{abstract}
Under global warming, crop pests such as nematodes are expected to develop faster and expand their geographical range. Temperature is known as a crucial factor in nematode population dynamics. We hypothesized that rising soil temperature will positively influence population densities of the sugar beet cyst nematode (Heterodera schachtii). An electric heating mat system with a semi-automatic temperature control was established to increase the soil temperature by 2.8 ${ }^{\circ} \mathrm{C}$ in heated compared to unheated 96-litre soil containers placed outdoors. Temperature, sugar beet cultivar and the interactions between these two parameters significantly affected the final number of cysts of $H$. schachtii recovered. The resistant cultivar 'Nemata' did not allow nematode reproduction in all treatments. Soil heating resulted in higher fresh weight in the beet cultivar 'Belladonna'. However, sugar beet fresh weights were lower in treatments challenged with $H$. schachtii. Percentages of white sugar content were significantly higher in nematode-free treatments. Based on these data we predict that an increase in soil temperature by $2.8{ }^{\circ} \mathrm{C}$ and cultivation of non-resistant cultivars will result in higher $H$. schachtii infestation levels in the soil.
\end{abstract}

Keywords - cyst nematodes, global warming, soil temperature, resistant cultivars 


\section{Introduction}

Global warming is projected to lead to an increase in mean air temperatures by $+2{ }^{\circ} \mathrm{C}$ by the year 2050 and up to $+4{ }^{\circ} \mathrm{C}$ by the year 2100 in northern Germany (Jacob and Podzun 1997; Werner and Gerstengarbe 2007). Several studies have shown that in a warmer climate, pests may become more active than they are currently and may expand their geographical range (Coakley et al. 1999; Garrett et al. 2006; Rosenzweig et al. 2001).

The sugar beet cyst nematode, Heterodera schachtii, is considered the most important nematode pest in sugar beet production causing an estimated yield loss of up to 25\% (Cooke 1991; Schlang 1991). Temperature is a major factor regulating the developmental rate and the population dynamics of beet cyst nematodes (Kakaire et al. 2012; Trudgill 1995). Elevated temperature levels may affect beet cyst nematodes directly by influencing their developmental rate (Griffin 1988; Trudgill 1995) and indirectly by altering host plant physiology (Chakraborty 2005). The developmental rate of $H$. schachtii has been shown to be linearly related to the temperature (Trudgill 1995). Therefore, predicted rising temperatures through global warming, can result in a faster nematode developmental rate, shorter life cycle durations with the potential that more generations could be completed in a growing season (Kakaire et al. 2012). Beet cyst nematodes mostly produce 2 to 3 generations per year in central Europe (Kakaire et al. 2015). The thermal time relationship (i.e. summation of cumulative differences between daily mean temperature and a specified base temperature expressed in degree-days) has also been used for a model of egg production of H. schachtii (Caswell and Thomason, 1991).

Soil temperature in the surface layer is significantly affected by seasonal changes in the air temperature (Jacobs et al. 2011). Despite the importance of soil temperature for the biology of nematodes, experiments focusing on the effect of increasing soil temperatures on nematode development under outdoor conditions have received little attention. Most studies aimed at understanding responses of nematodes to global warming have been conducted in Antarctica (Convey and Wynn-Williams 2002; Simmons et al. 2009; Sinclair 2002) or in other natural ecosystems (Bakonyi et al. 2007; Briones et al. 2009; Kardol et al. 2010), but not in agricultural systems. Recently, a soil warming system based on infrared heaters was used to investigate the response of nematodes to elevated temperature in conventional and no-tillage cropland systems (Dong et al. 2013). Heating cables have been proven to be a stable and reliable method for 
studying the effect of elevated soil temperatures on agricultural crops in soil ecosystems under field conditions (Patil et al. 2013; Siebold and von Tiedemann 2012). In this paper, we describe the application of an experimental soil heating system containing heating mats, to study warming effects on beet cyst nematode development on sugar beet. The aim of this study was to assess the effect of increased soil temperatures on the interaction between sugar beet cultivar and $H$. schachtii.

\section{Materials and methods}

\section{Heating mat system and control unit}

The heating system and the control unit method used in this study were adopted from a method used at the Institute for Sugar Beet Research (IfZ, Göttingen, Germany) to study the influence of soil warming on the development of beet necrotic yellow vein virus on sugar beet (Bornemann, pers comm.). The heating system consisted of a heating mat, a temperature controller, temperature sensors and a power supply. The heating mat type HMG (Hillesheim GmbH, Waghäusel, Germany) had a metal carrier and was directly plugged into the HTI 16 (Hillesheim GmbH Waghäusel, Germany) temperature controller. The temperature controller HTI 16 was set at $20{ }^{\circ} \mathrm{C}$. The integral controller measured the average temperature over the entire surface of the heating system directly from the heating wire and registered a temperature change immediately. The heating system operates with $3600 \mathrm{~W}$ heating energy. A temperature sensor (PT 100) monitored the temperature in the soil in order to switch on or off the heating until the set maximum temperature of $27^{\circ} \mathrm{C}$ of the heating mat was reached. The HTI 16 temperature controllers and two temperature data loggers (Testo 175 T3) were installed on a wooden board with a rain cover to avoid contact with water.

\section{Experimental design}

The experiments were located outdoors at the Julius Kühn-Institut, Braunschweig, Germany. The experimental set-up consisted of a two-factorial design with four unheated blocks (ambient temperature regime) and four heated blocks (increased temperature regime). Each block was a 96 1 rectangular plastic container filled with a $30 \mathrm{~cm}$ thick soil layer and with six 21 pots with a single beet plant. Each block consisted of 3 sugar beet cultivars and 2 nematode levels ( 0 and 10 
eggs and juveniles of $H$. schachtii per $\mathrm{cm}^{3}$ soil). Sugar beet cultivars 'Alabama' (susceptible to $H$. schachtii; KWS GmbH, Einbeck, Germany), 'Belladonna' (tolerant to H. schachtii; KWS $\mathrm{GmbH}$, Einbeck, Germany) and 'Nemata'(resistant to H. schachtii; Syngenta Seeds, Kleve, Germany) were seeded. Heating mats were placed on a layer of 201 steam-sterilised field soil. Above the heating mat, containers were filled with another layer of 701 steam-sterilised field soil. Soil medium had a $\mathrm{pH}$ of 5.3 , organic matter $26 \%$. The texture was clay $8.5 \%$, silt $21.3 \%$ and sand $70.2 \%$. The mineral content in the soil medium calculated in $\mathrm{mg} / 100 \mathrm{~g}$ of soil consisted of Potassium (K): 4mg/100g of soil, Phosphorous (P): 13mg/100g of soil and Magnesium (Mg): $3 \mathrm{mg} / 100 \mathrm{~g}$ of soil. Pots were filled with soil medium mixed with slow-release fertiliser (Osmocote Exact ${ }^{\circledR}$ Standard ${ }^{8} 15 \% \mathrm{~N}, 9 \% \mathrm{P}_{2} \mathrm{O}_{5}, 12 \% \mathrm{~K}_{2} \mathrm{O}$ and $2 \% \mathrm{MgO}$ ) at the rate of $2 \mathrm{~g} / \mathrm{kg}$. The average temperature difference between unheated and heated containers was set at $\pm 2.8{ }^{\circ} \mathrm{C}$. The total duration of the experiment was 19 weeks.

\section{Nematode culture and determination of initial and final nematode population densities}

The H. schachtii population used in this study was originally isolated from a sugar beet field in Germany and has been used in standard resistance tests (Müller and Rumpenhorst 2000). Pure cultures of this population were maintained on oilseed rape (Brassica napus L.) plants (cultivar Ladoga) in loess soil under greenhouse conditions at the Julius Kühn-Institut, Braunschweig.

Nematode inoculum in loess soil was mixed with the steam-sterilised loam soil, to obtain an initial population density of 10 eggs plus juveniles per $\mathrm{cm}^{3}$ of soil. Control treatments consisted of steam-sterilised loam mixed with loess soil.

Cysts were extracted at the onset of the experiment and after the experimental run to determine initial and final nematode population densities. Three subsamples of $100 \mathrm{~cm}^{3}$ soil were used to extract cysts using a MEKU high-pressure elutriator (MEKU, Wennigsen/Deister, Germany) with $40 \mathrm{~s}$ high pressure/5 s pause settings. Counting and separation of cysts from soil debris and other organic materials on the paper filter were carried out under a stereoscopic binocular (Leica MZ8). Cysts were crushed with a Janke and Kunkel homogenizer (IKA, Staufenberg, Germany) for $30 \mathrm{~s}$ at $1000 \mathrm{rpm}$ in plastic tubes in $1 \mathrm{ml}$ distilled water. The crushed sample was then washed into a beaker and topped up to $20 \mathrm{ml}$. Nematode suspensions were well mixed before aliquots of $1 \mathrm{ml}$ were taken. Number of eggs and juveniles were counted in $1 \mathrm{ml}$ counting slides under an 
inverted microscope (Axiovert25). Reproduction rates were calculated using the formula $\mathrm{Rf}=$ $\mathrm{Pf} / \mathrm{Pi}$ (Where $\mathrm{Rf}=$ reproduction factor, $\mathrm{Pf}=$ final nematode (eggs and juveniles) number per 100

$\mathrm{cm}^{3}$ soil from each treatment and $\mathrm{Pi}=$ initial nematode (eggs and juveniles) number per $100 \mathrm{~cm}^{3}$ soil from each treatment

\section{Assessment of sugar beet performance}

At harvest, pots were removed from the containers. Beet fresh weight was recorded after they were cleaned with a brush. Beets were cut, blended and the homogenous beet pulp was immediately shock frozen and stored at $-20^{\circ} \mathrm{C}$. The beet pulp was clarified with $0.3 \%(\mathrm{w} / \mathrm{v})$ $\mathrm{Al}_{2}\left(\mathrm{SO}_{4}\right)_{3}$-solution. In the filtrates, sugar content (sucrose) was assessed by polarimetry (ICUMSA 2003). White sugar content was calculated with the new 'Braunschweig formula' (Buchholz et al. 1995).

\section{Data analysis}

Data were analysed using SAS software Version 9.3 (SAS Institute Inc., Cary, NC, USA). Prior to analysis of variance (ANOVA), nematode counts were $\log$ transformed $\mathrm{y}=\log (\mathrm{x}+1)$ to standardize variances. Effects of soil heating, sugar beet cultivar and their interaction (independent variables) were analysed with regard to final number of cysts, number of eggs and juveniles, reproduction factor of $H$. schachtii, fresh beet weight, sugar content and white sugar content (dependent variables). The SAS mixed model (Proc mixed) with repeated measures was used to analyse the data. Means were separated using the Tukey HSD tests at 5\% confidence level.

\section{Results}

\section{Performance of heating mat system}

Soil temperature recordings (Fig. 1) showed that temperature of the heated containers was always above the temperature in the unheated containers, resulting in a positive temperature increase throughout the experiment. During the whole experimental period, the temperature regime in the heated containers was on average $2.8^{\circ} \mathrm{C}$ higher compared to the control (Table 1). 
Table 1: Soil temperature $\left({ }^{\circ} \mathrm{C}\right)$ measured at $10 \mathrm{~cm}$ depth in the unheated and heated containers over the entire experimental duration.

\begin{tabular}{ccc}
\hline & $\begin{array}{c}\text { Unheated } \\
\text { containers }\end{array}$ & $\begin{array}{c}\text { Heated } \\
\text { containers }\end{array}$ \\
\hline Mean soil temperature & $18.5 \pm 0.2$ & $21.3 \pm 0.5$ \\
Maximum soil temperature & 31.7 & 32.6 \\
Minimum soil temperature & 6.6 & 14.3 \\
\hline
\end{tabular}

The heated treatment followed the daily natural temperature fluctuations as recorded in the natural outdoor unheated treatment (Fig. 1). The temperature difference between unheated and heated plots was lower when ambient temperatures (e.g. in unheated plots) approached the set maximum temperature of $27^{\circ} \mathrm{C}$, so that extremely high temperatures and overheating was avoided, and maximum temperatures in unheated and heated plots were in the same range. The temperature difference between the heated and unheated containers was higher at lower ambient temperatures especially during the night-time, leading to an increased night-time warming effect.

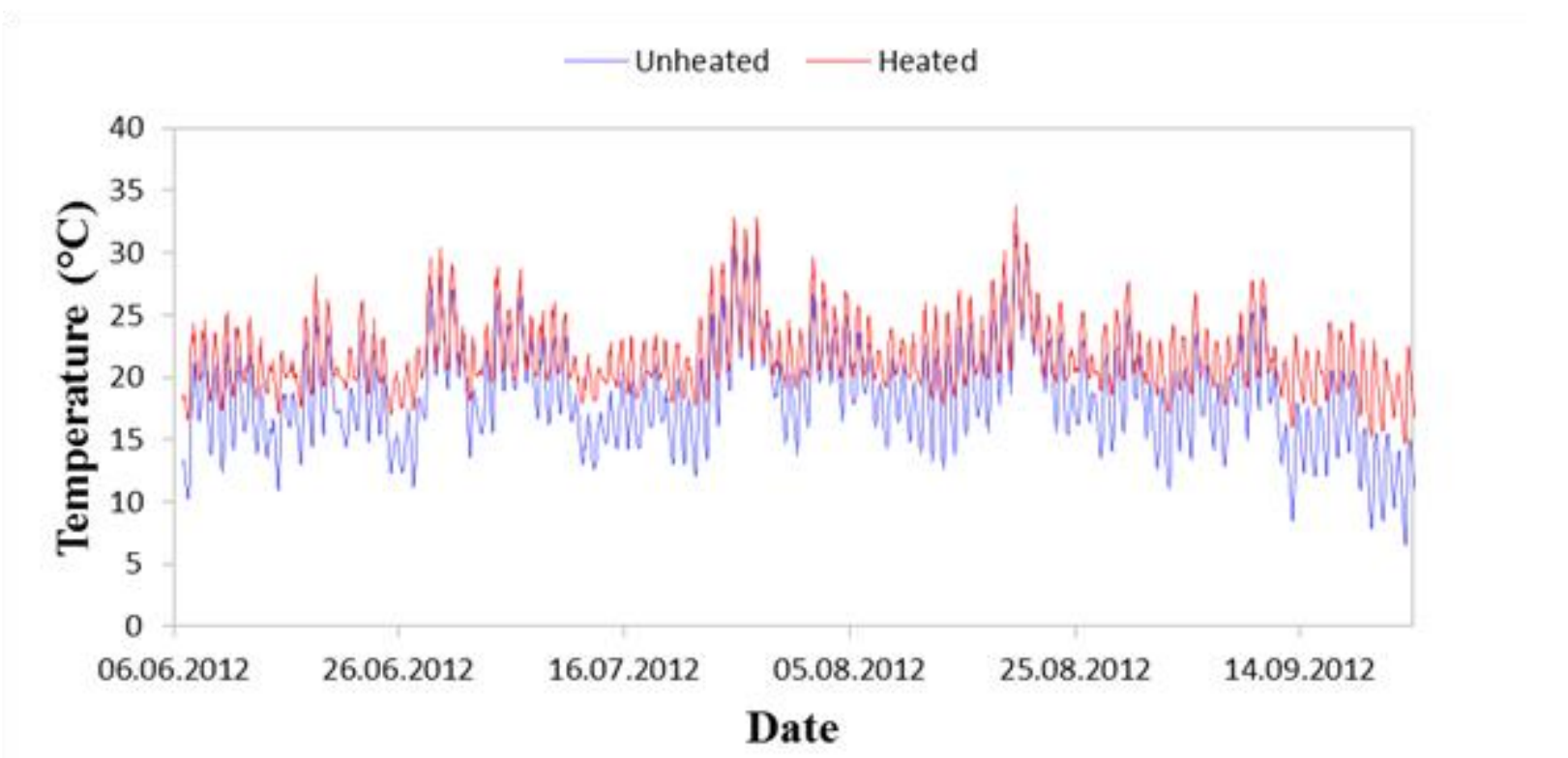

Fig. 1: Soil temperatures recorded in unheated (blue) and heated (red) blocks over the entire experimental duration from 6 June to 24 September 2012. 


\section{Effect of soil heating on $\mathrm{H}$. schachtii population development on different sugar beet cultivars}

Temperature, sugar beet cultivar, and their interaction significantly affected the final number of cysts of $H$. schachtii recovered (Table 2). The final number of eggs and second stage juveniles of H. schachtii was significantly affected by sugar beet cultivar (Table 2).

Table 2: $F$-values for effect of temperature (T) and sugar beet cultivar (C) on mean number of cysts and eggs plus second stage juveniles (J2) of H. schachtii from $100 \mathrm{~cm}^{3}$ soil.

\begin{tabular}{lccc}
\hline & T & C & T x C \\
\hline Cyst & $7.39^{*}$ & $317.45^{*}$ & $6.21^{*}$ \\
Eggs + J2 & 2.16 & $308.79^{*}$ & 1.82 \\
\hline$* \mathrm{P}<0.05$ & & &
\end{tabular}

Final number of eggs and second stage juveniles of $H$. schachtii recovered on the resistant cultivar 'Nemata' were lower than on susceptible cultivar 'Alabama' and tolerant cultivar 'Belladonna'(Table 3).

Table 3: Effect of temperature and sugar beet cultivar on the mean number of cysts and eggs plus second stage juveniles (J2) of $H$. schachtii from $100 \mathrm{~cm}^{3}$ soil. Values presented are means of four replicates (transformed means are in parentheses). Tukey test was used to separate the means at $\mathrm{P}<0.05$.

\begin{tabular}{lcc}
\hline & Cysts & Eggs + J2 \\
\hline Temperature & & \\
\hline Unheated & $360(2.2)^{\mathrm{b}}$ & $8972(3.4)^{\mathrm{a}}$ \\
Heated & $631(2.4)^{\mathrm{a}}$ & $13443(3.6)^{\mathrm{a}}$ \\
\hline Cultivar & & \\
\hline Alabama & $748(2.8)^{\mathrm{a}}$ & $15275(4.1)^{\mathrm{a}}$ \\
Belladonna & $717(2.9)^{\mathrm{a}}$ & $18090(4.2)^{\mathrm{a}}$ \\
Nemata & $22(1.3)^{\mathrm{b}}$ & $258(2.2)^{\mathrm{b}}$ \\
\hline
\end{tabular}


On the susceptible cultivar 'Alabama', H. schachtii reached a reproduction rate in the heated treatment about twice as high as in the unheated treatment (Fig. 2). The reproduction rate of $H$. schachtii, on the tolerant cultivar 'Belladonna' was not different from the susceptible cultivar Alabama. The resistant cultivar 'Nemata' did not allow nematode reproduction in both unheated and heated treatments.

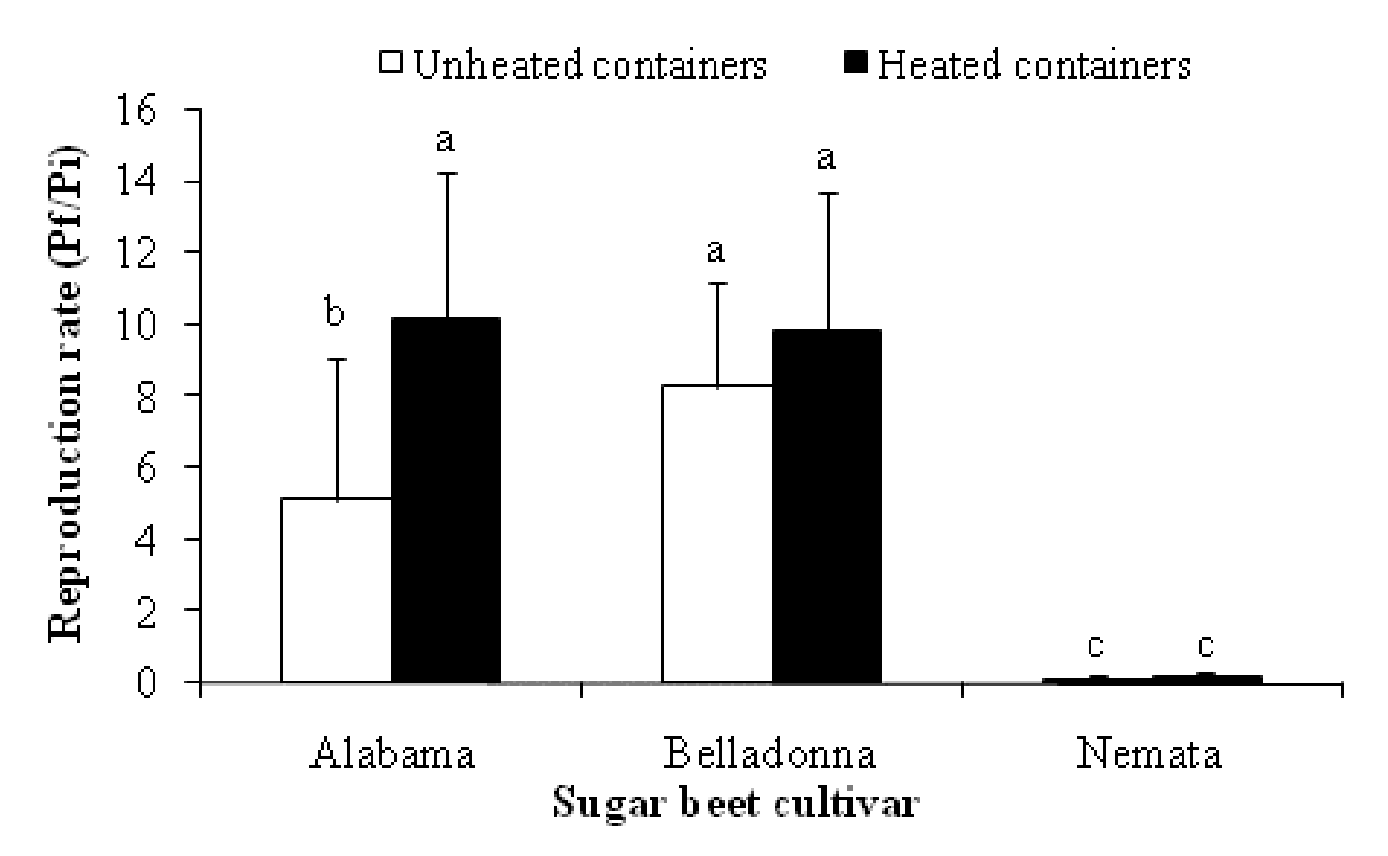

Fig. 2: Mean reproduction rates of Heterodera schachtii on sugar beet cultivars 'Alabama', 'Belladonna' and 'Nemata' in unheated and heated treatments after 19 weeks. Data shows mean \pm standard deviation. Tukey test was used to separate the means at $\mathrm{P}<0.05$ level. Means separated by different letters were significantly different.

\section{Effect of soil heating, sugar beet cultivar and nematodes on sugar beet performance}

Nematodes had a significant effect on sugar beet fresh weight, in both unheated- and heated plots. In nematode treatments, beet fresh weights did not differ between unheated and heated plots. Soil heating effects on sugar beet fresh weight were only significant in nematode-free treatments and were dependent on sugar beet cultivar, with either a neutral, positive or negative effect for the susceptible, tolerant and resistant cultivar, respectively. Sugar beet fresh weights of the cultivars 'Alabama' and 'Belladonna' were significantly lower in the nematode treatments 
than in the nematode-free treatments independent of soil heating (Fig. 3). Nematodes had a significant effect on sugar beet fresh weight of the resistant cultivar 'Nemata' in unheated blocks.

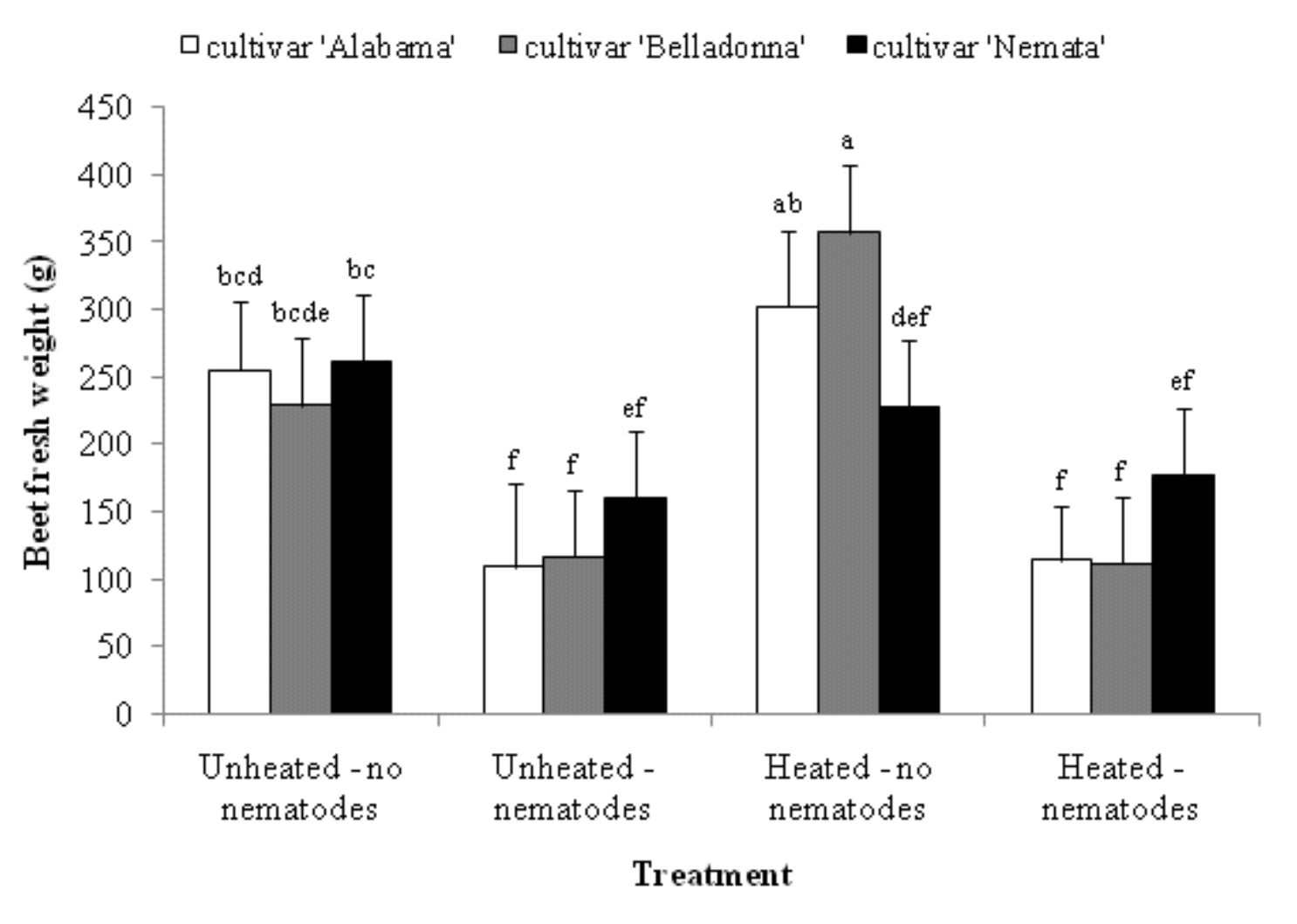

Fig. 3: Sugar beet fresh weights (g) of the sugar beet cultivars 'Alabama', 'Belladonna' and 'Nemata' across different heating- (unheated and heated) and nematode treatments (no nematodes and treated with beet cyst nematodes) after 19 weeks. Data show means \pm standard deviation. Tukey test was used to separate the means at $\mathrm{P}<0.05$ level. Means with different letters are significantly different.

Sugar beet cultivar and nematodes had a significant effect on white sugar content, with higher values on resistant cultivar 'Nemata' than on the tolerant cultivar 'Belladonna' (Table 4). 
Table 4: Effect of temperature, sugar beet cultivar and nematodes on mean white sugar content. Tukey test was used to separate the means at $\mathrm{P}<0.05$.

White sugar content

(\%)

\begin{tabular}{ll}
\hline Temperature & $11.052^{\mathrm{a}}$ \\
\hline Unheated & $14.740^{\mathrm{a}}$ \\
Heated & \\
\hline Cultivar & $12.862^{\mathrm{ab}}$ \\
\hline Alabama & $12.080^{\mathrm{b}}$ \\
Belladonna & $13.745^{\mathrm{a}}$ \\
Nemata & \\
\hline Nematode & $13.952^{\mathrm{a}}$ \\
\hline No nematodes & $11.839^{\mathrm{b}}$ \\
\hline Nematodes & \\
\hline
\end{tabular}

Percentages white sugar content were significantly lower in treatments challenged with nematodes (Table 5).

Table 5: F-values for effect of temperature (T), sugar beet cultivar $(\mathrm{C})$ and nematodes $(\mathrm{N})$ on white sugar content.

\begin{tabular}{lccccccc}
\hline & $\mathbf{T}$ & $\mathbf{C}$ & $\mathbf{N}$ & $\mathbf{T} \mathbf{C}$ & $\mathbf{T} \mathbf{x}$ & $\mathbf{C} \mathbf{x}$ & $\mathbf{T} \mathbf{C} \mathbf{~ N}$ \\
\hline White sugar content & 3.75 & $5.59 *$ & $26.83 *$ & 1.93 & 1.95 & 1.77 & 2.47 \\
\hline$* \mathrm{P}<0.05$ & & & & & & &
\end{tabular}




\section{Discussion}

\section{Performance of the heating mat system}

The heating mat system used in our experiment was able to maintain the targeted temperature difference throughout the experiment. The increased temperature regime followed closely the natural temperature fluctuations as observed in the unheated plots, which is considered important for the reliability of soil warming experiments (Aronson and McNulty 2009). Throughout our experiment, an average temperature increase of $2.8^{\circ} \mathrm{C}$ was attained concurring with observations made in other experiments using buried heating cables (Patil et al. 2013; Siebold and von Tiedemann 2012). Technically, heating was attained by a series of short heating pulses which were not long enough to allow the formation of extreme temperatures which could have lead to overheating and adverse effects on plant growth. Minimum soil temperatures differed more than maximum daily temperatures between unheated and heated treatments. This effect can be explained by the settings of the heating mat system, which is more effective (e.g. producing more heating pulses) at lower temperatures than at temperatures close to the set turn-off temperature of $27{ }^{\circ} \mathrm{C}$. The temperature difference was higher at lower ambient temperatures especially occurring during the night-time, leading to an increased night-time warming effect. Temperature data over the past five decades also show faster warming during the night than during the day and this asymmetric warming can have effects on plant biology (Peng et al. 2013). Additionally, nematodes could also be affected by higher minimum temperatures, since penetration rate and development of $H$. schachtii larvae is accelerated at soil temperatures above $10{ }^{\circ} \mathrm{C}$ (Griffin, 1981). In the heated treatment, this temperature threshold of $10{ }^{\circ} \mathrm{C}$ has been reached for the entire period of the experiment.

Although, warming with infrared heaters has proven to be a very reliable and realistic warming method (Aronson and McNulty 2009; Kimball et al. 2008), it often fails to establish a substantial rise in soil temperature, especially at lower depths (Aronson and McNulty 2009; Dong et al. 2013; Harte et al. 1996). In a recent study, responses of soil nematodes to soil warming by infrared radiators was investigated, but only an increase in daily soil temperature of $0.62{ }^{\circ} \mathrm{C}$ to $1.20{ }^{\circ} \mathrm{C}$ at $5 \mathrm{~cm}$ depth was reached (Dong et al. 2013). The results of our study showed that soil warming with a heating mat system is useful to study climate warming effects on the nematode population density and crop performance under outdoor conditions. It should be considered that 
heating mats unevenly distribute temperature through the soil profile as temperature is higher closer to the heating mat and effects on nematodes close to the heating mats cannot be excluded. However, temperature was set at a maximum of $27{ }^{\circ} \mathrm{C}$ in our experiment to avoid overheating and to account for this potential effect.

\section{Effect of soil heating on $\boldsymbol{H}$. schachtii population density on different sugar beet cultivars}

Previous studies under laboratory or greenhouse conditions on the effect of temperature on the population density of $H$. schachtii indicated a clear temperature effect, i.e. the higher the soil temperature the greater was the nematode reproduction rate (Griffin 1981; 1988; Santo and Bolander 1979). In our study, soil heating lead to a significant increase in final number of recovered cysts on tolerant cultivar 'Belladonna' and susceptible cultivar 'Alabama'. The resistant cultivar 'Nemata' did not allow nematode reproduction in both unheated- and heated treatments. The reproduction rates of $H$. schachtii on the tolerant cultivar 'Belladonna' were high and were not statistically different from the rate on the susceptible cultivar 'Alabama' under heated conditions. However, under unheated conditions, the reproduction rate on the tolerant cultivar 'Belladonna' was significantly higher than for 'Alabama'. These results were unexpected as most studies report lower Pf/Pi values on tolerant than on susceptible varieties (Daub and Westphal 2012; Niere 2009). Tolerant varieties are occasionally regarded as partly resistant due to their genetic background originating from Beta maritima, but they are unable to reduce the population density of $H$. schachtii (Daub and Westphal 2012; Niere 2009). The tested resistant sugar beet cultivar remained effective in reducing $H$. schachtii at higher temperatures. In the case of high nematode population densities and increasing soil temperatures, planting of nematode-resistant cultivars aiming at reducing nematode populations might become more important in the future.

\section{Effect of soil heating, sugar beet cultivar and nematodes on sugar beet performance}

Nematodes had a significant negative effect on sugar beet fresh weight. This effect differed by sugar beet cultivar but not by soil heating. Sugar beet fresh weights of the susceptible and tolerant were significantly lower in the nematode treatments than in the nematode-free treatments independent of soil heating. In our study, soil heating had overall no significant effect on sugar beet performance. However, the effect of soil heating was dependent on the sugar beet cultivar 
with either a neutral, positive or negative effect for the susceptible, tolerant and resistant cultivar, respectively

Sugar beet cultivar and nematodes had a significant effect on white sugar content, with higher values on resistant cultivar than on the tolerant cultivar. Percentages of white sugar content were significantly lower in treatments challenged with nematodes.

Accordingly, in previous studies, the main factors determining sugar yield were identified as nematode infestation and sugar beet cultivar (Hauer et al., 2016; Hauer et al., 2015). Sugar content of beets was shown to be negatively affected by root damage by beet cyst nematodes (Kenter et al. 2014). In contrast, Cooke and Thomason (1979) reported no effect of $H$. schachtii on sugar content. These contrasting effects could be related to the cultivars used, as there has been a significant breeding progress in sugar beets that might account for changes in plant responses (Loel et al., 2014). Susceptible cultivars evidenced a stronger decrease in sugar content than resistant cultivars, coinciding with an increase in $H$. schachtii population densities (Kenter et al. 2014). In the nematode treatments, white sugar content was higher for the resistant cultivar.

In conclusion, the results show that a heating mat system allows studying the effects of soil warming attributed to climate change on nematode density and crop performance under outdoor conditions. However, this approach also comes with some limitations. Indeed, the temperature difference was more than the envisaged $3{ }^{\circ} \mathrm{C}$ difference at low ambient temperatures and less than $3{ }^{\circ} \mathrm{C}$ at high ambient temperatures. The temperature is higher closer to the heating mat, which could influence nematode development. The combination of belowground soil warming and aboveground heaters (Thakur et al. 2014) should therefore be explored for studying effects of soil warming on nematode development and crop performance. The results of the present study indicate that future global warming with temperature increases of up to $\pm 3{ }^{\circ} \mathrm{C}$ and cultivation of non-resistant cultivars can result in higher $H$. schachtii populations in soil. Beet cyst nematodes negatively influenced sugar beet performance and effects of soil heating on sugar quality were dependent on sugar beet cultivar. Cultivar choice is an important element as the outcome of plant-nematode interactions varies greatly depending on the cultivar (Heijbroek et al., 2002; Kakaire et al., 2015). As in the last decades, there was a tremendous progress in breeding success, also breeding for resistance and tolerance to sugar beet pests, including beet 
cyst nematodes, will increase in significance (Heijbroek et al., 2002; Loel et al., 2014). Although positive effects on yield could also be expected due to the advance of phenological stages of sugar beet with higher temperatures in spring, this effect can be mitigated due to the earlier incidence of sugar beet pests, including beet cyst nematodes (Racca et al., 2015). As the multiplication rate is temperature dependent, it is expected that more generations can be completed in a growing season under increased temperature regimes. In a recent study on the number of generations it was confirmed that temperature was crucial in determining the number of generations of $H$. schachtii in a growing season on oil seed rape, but also there were clear differences depending on the cultivar used (Kakaire et al., 2015). Temperature has also been reported to influence the pathogenicity of nematodes, so that the damage threshold initial population density $(\mathrm{Pi})$ of $H$. schachtii on sugar beet grown in Germany declined from 20 eggs (g soil $^{-1}$ in April to 2.5 eggs (g soil) ${ }^{-1}$ in May as a result of an increase in soil temperature at planting (Steudel and Thielemann, 1970; Steudel and Thielemann, 1970). Further research using different sugar beet cultivars and different nematode species are needed to better understand the influence of soil warming on nematode development and crop performance.

\section{Acknowledgements}

We thank Dr. Eckard Moll for advice with the statistical analysis and Arno Littmann for help during the experimental set-up. This work was financially supported by the Ministry for Science and Culture of Lower Saxony, Germany, within the research network "KLIFF" - climate impact in Lower Saxony. 


\section{References}

Aronson EL \& McNulty SG, 2009. Appropriate experimental ecosystem warming methods by ecosystem, objective, and practicality. Agricultural and Forest Meteorology 149, 17911799.

Bakonyi G, Nagy P, Kovacs-Lang E, Kovacs E, Barabás S, Répási V \& Seres A, 2007. Soil nematode community structure as affected by temperature and moisture in a temperate semiarid shrubland. Applied Soil Ecology 37, 31-40.

Briones MJI, Ostle NJ, McNamara NP \& Poskitt J 2009. Functional shifts of grassland soil communities in response to soil warming. Soil Biology and Biochemistry 41, 315-322.

Buchholz K, Märländer B, Puke H, Glattkowski H \& Thielecke K, 1995. Neubewertung des technischen Wertes von Zuckerrüben. Zuckerindustrie 120, 113-121.

Burba M \& Georgi B, 1975. Fluorometric determination of amino acids in sugar beets and sugar factory products by fluorescamine and o-phthalaldehyde. Zeitschrift für die Zuckerindustrie 25, 667-673.

Caswell EP \& Thomason IJ, 1991. A model of egg production by Heterodera schachtii (Nematoda: Heteroderidae). Canadian journal of zoology 69, 2085-2088.

Chakraborty S, 2005. Potential impact of climate change on plant-pathogen interactions. Australasian Plant Pathology 34, 443-448.

Coakley SM, Scherm H \& Chakraborty S, 1999. Climate change and plant disease management. Annual Review of Phytopathology 37, 399-426.

Convey P \& Wynn-Williams, DD 2002. Antarctic soil nematode response to artificial climate amelioration. European Journal of Soil Biology 38, 255-259.

Cooke DA, 1991. The effect of beet cyst nematode, Heterodera schachtii, on the yield of sugar beet in organic soils. Annals of Applied Biology 118, 153-160.

Cooke DA \& Thomason IJ, 1979. The relationship between population density of Heterodera schachtii, soil temperature, and sugarbeet yields. Journal of Nematology 11, 124-128.

Daub M \& Westphal A, 2012. Integrated nematode management at crop rotation systems with sugar beets. Sugar Industry 137, 110-119. 
Dong ZK, Hou RX, Chen QY, Ouyang Z \& Ge F, 2013. Response of soil nematodes to elevated temperature in conventional and no-tillage cropland systems. Plant and Soil 373, 907918.

Duggan J, 1959. On the number of generations of beet eelworm, Heterodera schachtii Schmidt, produced in a year. Nematologica 4, 241-244.

Garrett KA, Dendy SP, Frank EE, Rouse MN \& Travers SE, 2006. Climate change effects on plant disease: Genomes to ecosystems. Annual Review of Phytopathology 44, 489-509.

Griffin G, 1981. The relationship of plant age, soil temperature, and population density of Heterodera schachtii on the growth of sugarbeet. Journal of Nematology 13, 184-190.

Griffin G 1988. Factors affecting the biology and pathogenicity of Heterodera schachtii on sugarbeet. Journal of Nematology 20, 396-404.

Heijbroek W, Munning RG \& van Swaaij ACPM, 2002. The effect of different levels of beet cyst nematodes (Heterodera schachtii) and beet necrotic yellow vein virus (BNYVV) on single and double resistant sugar beet cultivars. European Journal of Plant Pathology 108, 735-744.

Harte J, Rawa A \& Price V, 1996. Effects of manipulated soil microclimate on mesofaunal biomass and diversity. Soil Biology and Biochemistry 28, 313-322.

Hauer M, Koch HJ, Krüssel S, Mittler, S, \& Märländer, B (2016). Integrated control of Heterodera schachtii Schmidt in Central Europe by trap crop cultivation, sugar beet variety choice and nematicide application. Applied Soil Ecology, 99, 62-69.

Hauer M, Koch, HJ, \& Märländer B (2015). Water use efficiency of sugar beet cultivars (Beta vulgaris L.) susceptible, tolerant or resistant to Heterodera schachtii (Schmidt) in environments with contrasting infestation levels. Field Crops Research, 183, 356-364.

Jacob D \& Podzun R, 1997. Sensitivity studies with the regional climate model REMO. Meteorl Atmos Phys 63, 119-129.

Jacobs AF, Heusinkveld BG \& Holtslag AA, 2011. Long-term record and analysis of soil temperatures and soil heat fluxes in a grassland area, The Netherlands. Agricultural and Forest Meteorology 151, 774-780.

Jones P, Lister D, Jaggard K \& Pidgeon J, 2003. Future climate impact on the productivity of sugar beet (Beta vulgaris L.) in Europe. Climatic Change 58, 93-108. 
Kakaire S, Grove I \& Haydock P, 2012. Effect of temperature on the life cycle of Heterodera schachtii infecting oilseed rape (Brassica napus L.). Nematology 14, 855-867.

Kakaire S, Grove IG \& Haydock PPJ, 2015. The number of generations of Heterodera schachtii completed on oilseed rape (Brassica napus L.) during the UK growing season. Nematology 17, 557-565.

Kardol P, Cregger MA, Campany CE \& Classen AT, 2010. Soil ecosystem functioning under climate change: plant species and community effects. Ecology 91, 767-781.

Kenter C, Lukashyk P, Daub M \& Ladewig E, 2014. Population dynamics of Heterodera schachtii Schm. and yield response of susceptible and resistant sugar beet (Beta vulgaris L.) after cultivation of susceptible and resistant oilseed radish (Raphanus sativus L.). Journal für Kulturpflanzen 66, 289-299.

Kimball BA, Conley MM, Wang S, Lin X, Luo C, Morgan J \& Smith D, 2008. Infrared heater arrays for warming ecosystem field plots. Global Change Biology 14, 309-320.

Loel J, Kenter C, Märländer B \& Hoffmann CM, 2014. Assessment of breeding progress in sugar beet by testing old and new varieties under greenhouse and field conditions. European Journal of Agronomy 52, Part B, 146-156

Müller J \& Rumpenhorst H, 2000. Die Prüfung von Pflanzen auf ihre Widerstandsfähigkeit gegen Schadorganismen in der Biologischen Bundesanstalt. Teil 1 Prüfung von Kulturpflanzen auf Resistenz gegen pflanzenparasitäre Nematoden. Mitt Biol Bundesanst Land-Forstwirtsch Berlin-Dahlem 372, 38.

Niere B, 2009. Principles of beet cyst nematode management. Sugar Industry 134, 186-192.

Patil RH, Laegdsmand M, Olesen JE \& Porter JR, 2013. Soil temperature manipulation to study global warming effects in arable land: Performance of buried heating-cable method. Environment and Ecology Research 1, 196-204.

Peng S, Piao S, Ciais P, Myneni RB, Chen A, Chevallier F, Dolman AJ, Janssens IA, Penuelas J \& Zhang G, 2013. Asymmetric effects of daytime and night-time warming on Northern Hemisphere vegetation. Nature 501, 88-92.

Qi A, Kenter C, Hoffmann C \& Jaggard K, 2005. The Broom's Barn sugar beet growth model and its adaptation to soils with varied available water content. European Journal of Agronomy 23, 108-122. 
Racca P, Kakau J, Kleinhen, B \& Kuhn C, 2015. Impact of climate change on the phenological development of winter wheat, sugar beet and winter oilseed rape in Lower Saxony, Germany. Journal of Plant Diseases and Protection 122, 16-27.

Richter G, Qi A, Semenov M \& Jaggard K, 2006. Modeling the variability of UK sugar beet yields under climate change and husbandry adaptations. Soil Use and Management 22, $39-47$.

Rosenzweig C, Iglesias A, Yang XB, Epstein P \& Chivian E, 2001. Climate change and extreme weather events: Implications for food production, plant diseases and pests. Global Change \& Human Health 2, 90-104.

Santo G \& Bolander W, 1979. Interacting effects of soil temperature and type on reproduction and pathogenicity of Heterodera schachtii and Meloidogyne hapla on sugarbeets. Journal of Nematology 11, 289-291.

Schlang J, 1991. Anbau resistenter Zwischenfrüchte zur biologischen Bekämpfung des Rübenzystennematoden. Zuckerrübe 40.

Schneider F, 1979. Sugar analysis: ICUMSA methods. ICUMSA.

Scott R \& Jaggard K 2000. Impact of weather, agronomy and breeding on yields of sugarbeet grown in the UK since 1970. The Journal of Agricultural Science 134, 341-352.

Siebold M, von Tiedemann A, 2012. Application of a robust experimental method to study soil warming effects on oilseed rape. Agricultural and Forest Meteorology 164, 20-28.

Simmons BL, Wall DH, Adams BJ, Ayres E, Barrett JE \& Virginia RA 2009. Long-term experimental warming reduces soil nematode populations in the McMurdo Dry Valleys, Antarctica. Soil Biology and Biochemistry 41, 2052-2060.

Sinclair BJ, 2002. Effects of increased temperatures simulating climate change on terrestrial invertebrates on Ross Island, Antarctica. Pedobiologia 46, 150-160.

Steudel W \& Thielemann R, 1970. Weitere Untersuchungen zur Frage der Empfindlichkeit von Zuckerrüben gegen den Rübennematoden (Heterodera schachtii Schmidt). Zucker 23, 106-109.

Thakur M, Reich P, Fisichelli N, Stefanski A, Cesarz S, Dobies T, Rich R, Hobbie S \& Eisenhauer N, 2014. Nematode community shifts in response to experimental warming and canopy conditions are associated with plant community changes in the temperateboreal forest ecotone. Oecologia 175, 713-723. 
Trudgill D, 1995. An assessment of the relevance of thermal time relationships to nematology. Fundamental and Applied Nematology 18, 407-417.

ICUMSA (2003): International Commission for Uniform Methods of Sugar Analysis Methods Book, Colney, Norwich.

Werner PC, Gerstengarbe FW 2007. Welche Klimaänderungen sind in Deutschland zu erwarten? In: Endlicher W and Gerstengarbe FW (ed) Der Klimawandel-Einblicke, Rückblicke und Ausblicke. Potsdam-Institut für Klimafolgenforschung und Humboldt-Universität zu Berlin, Berlin/Potsdam pp 56-59. 


\title{
Chapter 4:
}

\section{Influence of temperature on the interspecific competition between the beet} cyst nematode species Heterodera schachtii and Heterodera betae on sugar beet

\author{
Bart AB Vandenbossche ${ }^{1,3}$, Holger Heuer ${ }^{2}$, Björn Niere $^{1}$ and Stefan Vidal ${ }^{3}$ \\ ${ }^{1}$ Julius Kühn-Institut (JKI), Federal Research Centre for Cultivated Plants, Institute for National \\ and International Plant Health, Messeweg 11/12, 38104 Braunschweig, Germany \\ ${ }^{2}$ Julius Kühn-Institut, Federal Research Centre for Cultivated Plants, Institute for Epidemiology \\ and Pathogen Diagnostics, Messeweg 11/12, 38104 Braunschweig, Germany \\ ${ }^{3}$ Georg-August-University Göttingen, Department of Crop Sciences, Section Agricultural \\ Entomology, Grisebachstrasse 6, 37077 Göttingen, Germany
}

Corresponding author, e-mail: bavdenbo.vandenbossche@gmail.com

* Chapter in preparation for submission to a peer-reviewed journal

Vandenbossche B.A.B., Heuer, H., Niere B., Vidal S. (2016). Influence of temperature on the interspecific competition between the beet cyst nematode species Heterodera schachtii and Heterodera betae on sugar beet 


\begin{abstract}
Beet cyst nematodes are one of the most important pests of sugar beet. The two beet cyst nematode species, Heterodera schachtii and Heterodera betae, can occur in mixed populations but information about how the species behave in co-occurrence is very limited. Temperature is an important factor shaping nematode development and interactions between related species. Predicted global warming may shorten the generation time of nematodes which may increase the population density and dominance of species better adapted to higher temperatures. We studied the effect of increased temperature on the interspecific competition between $H$. schachtii and $H$. betae. In two climate chambers differing in temperature by $4{ }^{\circ} \mathrm{C}$, sugar beets were grown in loess infested with of 10 nematodes per $\mathrm{ml}$ of soil of either $\mathrm{H}$. schachtii, or $\mathrm{H}$. betae, or $50 \%$ mixtures of both. To determine the relative abundance of both species in mixed populations, a quantitative PCR system was developed for both species based on sequence differences in the cytochrome oxidase subunit 1 gene. Both beet cyst nematode species performed better at higher temperature. A higher number of cysts and juveniles of $H$. schachtii than from $H$. betae were recovered in pots with a single inoculated species. A significant difference in the competitive ability of both species under both temperature regimes could not be observed. However, the trend that $H$. schachtii multiplied slightly better than $H$. betae in competition was alleviated at higher temperature. In conclusion, the damage done by cyst nematodes in sugar beet is expected to increase with global warming. $H$. schachtii and $H$. betae are likely to continue to cause damages. But neither of the two species will profit more from rising temperatures compared to the other.
\end{abstract}

Keywords: global warming, soil temperature, real-time PCR 


\section{Introduction}

Temperature is often the most important environmental factor affecting nematode biology (Trudgill, 1995). Different species have different optimum temperatures for feeding, hatching, reproduction and survival (Neilson \& Boag, 1996). Predicted climate change may shorten the generation time of nematodes which may increase the population density and dominance of species better adapted to higher temperatures (Kakaire et al., 2012; Kaczmarek et al., 2014). For example, the two species of potato cyst nematodes, Globodera pallida and Globodera rostochiensis, differ in their temperature responses (Franco, 1979; Kaczmarek et al., 2014). Low soil temperatures are likely to favour G. pallida whereas warmer temperatures are likely to favour G. rostochiensis, which hatches more quickly (Franco, 1979). This has implications for interspecific competition between the two cyst nematode species at different temperatures, when they occur as mixed populations in the field and lead to different host responses and final nematode populations (Kaczmarek et al., 2014). In the case of two closely related species as Heterodera schachtii and Heterodera betae, interactions are expected to be mutually antagonistic as they compete for the available feeding sites (Den Nijs \& Lock, 1990). Heterodera schachtii is considered as one of the most important nematode pests on sugar beet and is present in most sugar beet growing areas (Cooke, 1991). The yellow beet cyst nematode, H. betae, is less prevalent but has also been found damaging beet crops (Maas \& Heijbroek, 1982). The host ranges of $H$. schachtii and $H$. betae were shown to be very similar, and both species have been shown to co-occur in mixed populations in several locations in France, Spain and Belgium (Gracianne et al., 2014). In that study, it was hypothesised that $H$. betae derives from $H$. schachtii as a result of speciation by polyploidy and that $H$. betae is better adapted to warmer habitats (Gracianne et al., 2014). However, knowledge on how both species behave in cooccurrence is very limited.

H. schachtii and $H$. betae have similar morphology but have minor differences in size (Amiri et $a l ., 2003)$. The traditional identification using morphological characteristics is time-consuming and requires specialized taxonomic skill, especially in the case of species mixtures (Fleming et al., 1998). Alternatively, quantitative PCR can enable rapid detection and quantification of target species (Powers, 2004). Molecular quantification techniques have significantly evolved during 
the last decade and can also be applied to explore ecological interactions (Torr et al., 2007; Campos Herrera et al., 2015). Despite the high potential of current PCR-based methods, they are until now only rarely used in nematode ecology. The combination of traditional and molecular detection methods was able to reveal intense competition of entomopathogenic nematodes with other free-living nematodes (Campos Herrera et al., 2015) and study habitat associations between different entomopathogenic nematodes (Torr et al., 2007).

In this study, we investigated how populations of both species develop in co-occurrence, and whether temperature affects the interspecific competition between the beet cyst nematode species. The objectives of this study were: 1) to determine the effect of temperature on the population dynamics of $H$. schachtii and $H$. betae in interspecific competition and 2) to design a real-time based PCR method for the detection of the relative proportions of $H$. schachtii and $H$. betae.

\section{Materials and methods}

\section{Plant cultivation}

The cultivar 'Alabama' was selected for this experiment due to its susceptibility to $H$. schachtii (KWS, Einbeck, Germany). Three sugar beet seeds of this variety were planted per pot in $500 \mathrm{ml}$ volume plastic pots in pure underground loess (Müller \& Rumpenhorst, 2000). Slow release fertiliser (Osmocote Exact ${ }^{\circledR}$ Standard ${ }^{\circ}$ 15\% N, 9\% P2O5, 12\% K2O and 2\% MgO) was added to the soil at $2 \mathrm{~g} / \mathrm{kg}$ of loess. Seedlings were allowed to germinate and grow at a 14/10 hours light/dark regime for three weeks till they reached the four-leaf stadium $(\mathrm{BBCH} 14)$ and were then thinned out to one plant per pot.

\section{Nematodes}

The H. schachtii population used in this study was originally isolated from a sugar beet field in Germany and is used in standard resistance tests (Müller \& Rumpenhorst, 2000). The H. betae population was isolated from a sugar beet field in Elsdorf, North Rhine-Westphalia, Germany. Pure cultures of these populations were maintained on oilseed rape plants (cultivar Ladoga) at the Julius Kühn-Institut, Braunschweig (Germany). 
Cysts out of the pure cultures were extracted using a MEKU high-pressure elutriator (MEKU, Wennigsen/Deister, Germany) with $40 \mathrm{~s}$ high pressure/5 s pause settings. Counting and separation of cysts from soil debris and other organic materials were carried out under a stereoscopic binocular (Leica MZ8). Cysts were placed on Bearmann funnels in a $3 \mathrm{mM} \mathrm{ZnCl}_{2^{-}}$ solution to stimulate the emergence of second-stage juveniles (Müller \& Rumpenhorst, 2000). The nematode suspension was tapped off every two days. Nematode stock was stored at approximately $4{ }^{\circ} \mathrm{C}$ until further use. To estimate the population density, the stock solutions were stirred and total nematode numbers determined using a $1 \mathrm{ml}$ sub-sample from the stock, counted at 40X magnification using an Axiovert 25 (Carl Zeiss $\left.{ }^{\circledR}\right)$ inverted microscope. The counting was replicated three times and the mean count calculated. The initial population density (Pi) was adjusted to 10 nematodes/ml. Nematodes were applied one day after thinning out until one plant per pot.

\section{Experimental design}

Experiments were conducted in two climate chambers. In the first climate chamber, a standard climate regime was set to $18{ }^{\circ} \mathrm{C}$ day $/ 8{ }^{\circ} \mathrm{C}$ night and in the second climate chamber the regime was set to $22{ }^{\circ} \mathrm{C}$ day $/ 12{ }^{\circ} \mathrm{C}$ night. For both temperature regimes, the treatments were the following: control treatment (no nematodes), inoculation with $H$. schachtii, inoculation with $H$. betae, inoculation with both $H$. schachtii $(50 \%)$ and $H$. betae $(50 \%)$. Ten replicates per treatment were used. Initial population density of the nematode treatments was 10 second stage juveniles per $\mathrm{ml}$ soil. Control pots received the same amount of water. Pots in each climate chamber were placed in a complete randomized design. Two Testo T175A data loggers were installed with sensors at $5 \mathrm{~cm}$ depth inside the soil. The total duration of the experiment from inoculation till termination was 15 weeks.

\section{Data collection}

Experiments were terminated by turning the pots upside down through a sieve to a soil collection container after chopping off the beet leaves. Three subsamples of $100 \mathrm{ml}$ were used to extract cysts using a MEKU high-pressure elutriator (MEKU, Wennigsen/Deister, Germany) with $40 \mathrm{~s}$ high pressure/5 s pause settings. Cysts were extracted as described above to determine final 
nematode population densities. Cysts were crushed with a Janke and Kunkel homogenizer (IKA, Staufenberg, Germany) for $30 \mathrm{~s}$ at $1000 \mathrm{rpm}$ in plastic tubes in $1 \mathrm{ml}$ distilled water. The crushed sample was then washed into a beaker and topped till a concentration of around 400-500 juveniles per ml was attained, which was continuously agitated before pipetting off $1 \mathrm{ml}$ of the suspension into nematode counting slide and counting the number of eggs and juveniles in $1 \mathrm{ml}$ counting slides (Shepherd, 1986).

\section{Morphological quantification of nematodes}

Nematode numbers (eggs and second stage juveniles) from $100 \mathrm{ml}$ of soil were determined under an inverted microscope (Axiovert25 CarlZeiss ${ }^{\circledR}$ ) at 40X magnification using a nematode counting slide chamber of $1 \mathrm{ml}$ capacity.

\section{Primer and probe sets: design and specificity of primers}

H. schachtii and H. betae species-specific primers and probes were designed for the cytochrome oxidase subunit 1 (COI) gene (Table 1). For sequence determination COI was amplified by adding $1 \mu \mathrm{DNA}$ of the selected species to the PCR reaction mixture containing $\mathrm{x} 0,25 \mu \mathrm{l}$ of TrueStart HotStart Taq DNA Polymerase (Thermo Scientific, Wilmington, DE, USA) $1 \mu \mathrm{M}$ of forward primer JB3 (5'-TTT TTT GGG CAT CCT GAG GTT TAT-3') (Bowles et al. 1992), 1 $\mu \mathrm{M}$ of the reverse primer JB5 (5'-AGC ACC TAA ACT TAA AAC ATA ATG AAA ATG-3') (Derycke et al. 2005), and ddH2O up to a final volume of $50 \mu$ l. The PCR program settings were as follows: initial denaturation step at $95{ }^{\circ} \mathrm{C}$ for $5 \mathrm{~min}$; 40 cycles of $95{ }^{\circ} \mathrm{C}$ for $30 \mathrm{~s}, 41{ }^{\circ} \mathrm{C}$ for $30 \mathrm{~s}$ and $72{ }^{\circ} \mathrm{C}$ for $45 \mathrm{~s}$; and an additional amplification step at $72{ }^{\circ} \mathrm{C}$ for $8 \mathrm{~min}$.

\section{DNA extraction}

DNA was extracted out of $1 \mathrm{ml}$ nematode suspension (with nematode numbers estimated before by microscopic counting as described above) using manufacturer's protocol for extraction out of animal tissue of the QIAMP DNA Mini Kit (Qiagen). The DNA was resuspended in $200 \mu \mathrm{L}$ of elution buffer and stored at $-20{ }^{\circ} \mathrm{C}$ until use. All DNA samples were analysed using $1 \mu \mathrm{L}$ per duplicate in a Nanodrop ND-1000 v3.3.0 (Thermo Scientific) to estimate the quality and quantity. 


\section{Cloning and sequencing}

PCR products from the COI were cloned using the vector pGEM®-T Easy and Escherichia coli JM109 high-efficiency competent cells (Promega, Madison, WI, USA) which were used for transformation of the ligation product. The resultant plasmid DNA obtained from the Escherichia coli culture was purified following the PureYield ${ }^{\mathrm{TM}}$ Plasmid Miniprep System (Promega GmbH, Mannheim, Germany) guidelines. Samples were sequenced on both strands byMacrogen Europe (Amsterdam, The Netherlands). Plasmid DNA concentrations were determined by measuring the optical density using a spectrophotometer (Nanodrop ND-1000 v3.3.0, Thermo Scientific).

\section{Molecular quantification: TaqMan assay}

The oligonucleotide sequences designed for use with $H$. schachtii from forward primer, reverse primer and TaqMan probe respectively are presented in Table 1. Gel electrophoresis for PCR products of both primer sets showed amplification of a product of the desired length. qPCR was performed using the CFX96TM Real-Time System (BioRad, Munich, Germany).

Real-time PCR reaction mixture contained $0.25 \mu 1$ of TrueStart HotStart Taq DNA Polymerase (Thermo Scientific, Wilmington, DE, USA), $5 \mu 1$ Truestart buffer, $5 \mu 12 \mathrm{mM}$ dNTP, $5 \mu 125 \mathrm{mM}$ $\mathrm{MgCl} 2,1.5 \mu \mathrm{l} 10 \mu \mathrm{M}$ forward primer, $1.5 \mu \mathrm{l}$ of the $10 \mu \mathrm{M}$ reverse primer, $1.5 \mu \mathrm{l}$ of the $10 \mu \mathrm{M}$ hydrolysis $\left(\right.$ Taqman $\left.{ }^{\circledR}\right)$ probe and $\mathrm{ddH} 2 \mathrm{O}$ up to a final volume of $50 \mu$. The PCR program settings were as follows: initial denaturation step at $95{ }^{\circ} \mathrm{C}$ for $5 \mathrm{~min} ; 40$ cycles of $94{ }^{\circ} \mathrm{C}$ for $15 \mathrm{~s}$, $60{ }^{\circ} \mathrm{C}$ for $1 \mathrm{~min}$ with detection of released FAM. Pearson correlation analysis showed a significant correlation between microscopic counts and qPCR estimates of number of beet cyst nematodes in samples (R-Square $=0.615, \mathrm{P}=0.003$ ). Linear regression analysis revealed a positive relationship between microscopic counts and number of genes in $1 \mathrm{ml}$ samples of $\mathrm{y}=$ $1.369 \mathrm{x}+2.133$ for $H$. schachtii and $\mathrm{y}=1.770 \mathrm{x}+0.133$ for $H$. betae (with $\mathrm{x}$ is the $\log 10$ of microscopically counted nematodes per $\mathrm{ml}$ and $\mathrm{y}$ is the $\log 10$ of the number of genes per $\mathrm{ml}$ ). 
Table 1: Specific primers and TaqMan probes for detecting Heterodera schachtii and H. betae.

\begin{tabular}{lll}
\hline Species & Name & Primer and probe (5'-3') \\
$\begin{array}{lll}\text { Heterodera } \\
\text { schachtii }\end{array}$ & HsCOI175f & F: GCCTATTTTAGAGCAGCTACT \\
& HsCOI255r & R: ACCATAAATCCTCATTAGTCAA \\
& HsCOI203tp & $\begin{array}{l}\text { P: FAM-TTGCTATTCCAACTGGTATTAAGGTTT- } \\
\text { 3'-TAMRA }\end{array}$ \\
Heterodera betae & HbCOI110f & F: GTTTTATTGGCTGTTTGGT \\
& HbCOI194r & R: GTTGCTGCTCTAAAATAAGC \\
& HbCOI138tp & $\begin{array}{l}\text { P: FAM- } \\
\text { CCATATATTTGTGGTTGGAATAGATATGG-3'- } \\
\end{array}$ \\
& & TAMRA \\
\hline
\end{tabular}

Code: F forward primer, R reverse primer, P TaqMan® Probe

\section{Data analysis}

Data was analysed using SAS software Version 9.3 (SAS Institute Inc., Cary, NC, USA). Prior to analysis of variance, nematode counts were $\log$ transformed $\mathrm{y}=\log (\mathrm{x}+1)$ to standardize variance. Effects of temperature, nematode and their interaction on final number of cysts and number of juveniles were evaluated. The mixed model (MIXED) procedure was used to analyse the data. Tukey studentized range test was used to separate means at 5\% confidence level. Data on relative abundance was analysed with Kruskal-Wallis test and multiple comparisons with Dunn procedure. Significance level was corrected with Bonferroni procedure.

\section{Results}

Effect of temperature and species on final number of cysts and second stage juveniles 
The effect of a $4{ }^{\circ} \mathrm{C}$ temperature increase on the population development of $H$. schachtii and $H$. betae was tested. The effect of temperature and nematode initial population densities on the final number of cysts and second stage juveniles (J2) of the respective beet cyst nematodes and interaction effects are shown in Table 2. Temperature had a significant effect on the final number of cysts $(\mathrm{F}=638.48 ; \mathrm{P}<0.0001)$ and second stage juveniles $(\mathrm{F}=798.66 ; \mathrm{P}<0.001)$. In the increased temperature regime (Ti), a significantly higher final amount of cysts and $\mathbf{J} 2$ were recovered than in the standard temperature regime (Ts) for both beet cyst nematode species. Beet cyst nematode species had a significant effect on the final number of cysts $(\mathrm{F}=15.13 ; \mathrm{P}<$ $0.0001)$ and juveniles $(\mathrm{F}=7 ; \mathrm{P}<0.001)$.

Table 2: Effect of temperature, nematode treatment and their interaction on the final number of cysts and eggs plus second stage juveniles (J2) of H. schachtii from $100 \mathrm{ml}$ soil.

\begin{tabular}{|c|c|c|}
\hline & Cysts & Eggs $+\mathrm{J} 2$ \\
\hline \multicolumn{3}{|l|}{ Temperature } \\
\hline Standard temperature regime $(\mathrm{Ts})$ & $87^{\mathrm{b}}$ & $10761^{\mathrm{b}}$ \\
\hline Increased temperature regime $(\mathrm{Ti})$ & $672^{\mathrm{a}}$ & $84498^{\mathrm{a}}$ \\
\hline F-value & 638.48 & 798.66 \\
\hline $\mathrm{P}$-value & $<0.0001$ & $<0.001$ \\
\hline \multicolumn{3}{|c|}{ Nematode treatment } \\
\hline H. schachtii & $476^{\mathrm{a}}$ & $60212^{\mathrm{a}}$ \\
\hline H. betae & $330^{\mathrm{b}}$ & $39524^{\mathrm{b}}$ \\
\hline H. schachtii + H. betae & $331^{\mathrm{b}}$ & $43153^{\mathrm{b}}$ \\
\hline F-value & 15.13 & 7,00 \\
\hline P-value & $<0.0001$ & $<0.002$ \\
\hline \multicolumn{3}{|c|}{ Temperature $\mathrm{x}$ Nematode } \\
\hline F-value & 1.33 & 1.22 \\
\hline P-value & 0.274 & 0.303 \\
\hline
\end{tabular}

Statistical analysis was performed on $\log$ transformed data $(y=\log (\mathrm{x}+1))$. Values presented are means of ten replicates. Tukey studentized range test was used to separate the means at $\mathrm{P}<0.05$ level. Means separated by different letters were significantly different.

Final number of nematodes recorded for $H$. schachtii was higher than for $H$. betae alone and in the treatment with both $H$. schachtii and $H$. betae, in the increased temperature regime (Fig. 1). 
At the standard temperature regime, there was no difference in total nematode numbers between different nematode treatments.

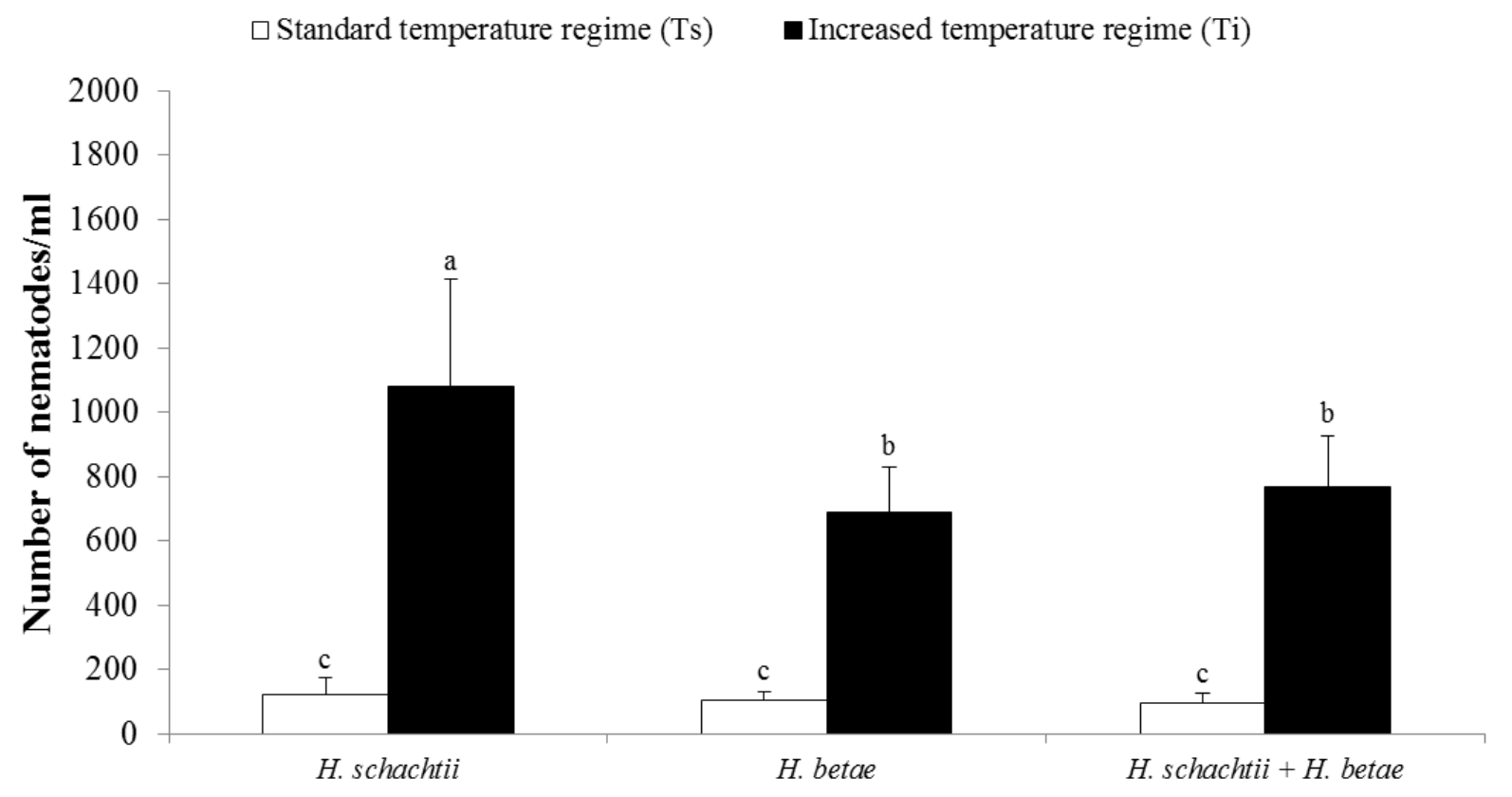

Fig. 1. Final nematode population density across the different temperature and nematode treatments as estimated by counting. Data shows means + standard deviation. Tukey studentized Range Test was used to separate the means at $\mathrm{P}<0.05$ level. Means separated by different letters are significantly different from each other.

\section{Influence of temperature on relative proportions of $\boldsymbol{H}$. schachtii and $\boldsymbol{H}$. betae}

Final percentages of $H$. schachtii signal in mixed treatments with an initial inoculation of 50\% Heterodera schachtii and 50\% $\mathrm{H}$. betae were not significantly different between the temperature regimes (Fig. 2). In the standard temperature regime, the relative proportions were $59 \% H$. schachtii and $41 \% \mathrm{H}$. betae. In the increased temperature regime, the proportions were $53 \% \mathrm{H}$. schachtii and $47 \% \mathrm{H}$. betae. Although these differences in relative proportions were not significant, the data suggest a slightly better performance of $H$. schachtii relative to $H$. betae. 


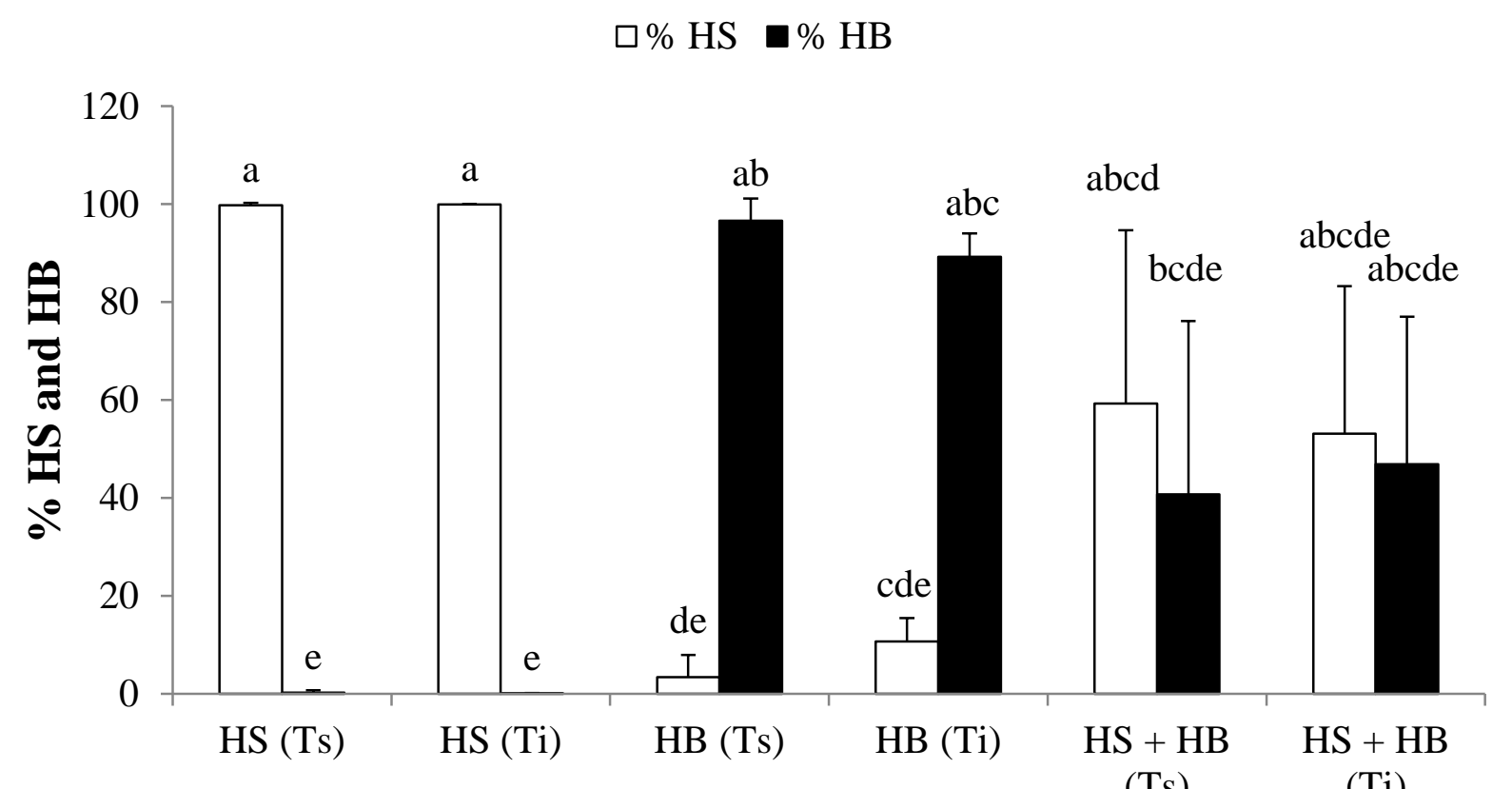

Fig. 2. Final percentual proportion of $H$. schachtii signal in treatments with $H$. schachtii (HS), H. betae (HB) and with $50 \% \mathrm{H}$. schachtii and 50\% H. betae (HS + HB) in standard temperature regime (Ts) and increased temperature regime $(\mathrm{Ti})$. Data shows mean + standard deviation. Data was analysed with Kruskal-Wallis test and multiple comparisons with Dunn procedure. Significance level was corrected with Bonferroni procedure. Means separated by different letters are significantly different from each other.

In these mixed treatments, the data range was large, meaning that among replicates there are samples containing more $H$. schachtii and others containing more $H$. betae (Fig 3.). No clear effect of competition between both beet cyst nematode species in species mixtures under elevated temperature could be detected. In case of single-species inoculations, it is expected that both species perform better under elevated temperatures. More specifically, $H$. schachtii performed better than $H$. betae under increased temperatures. 


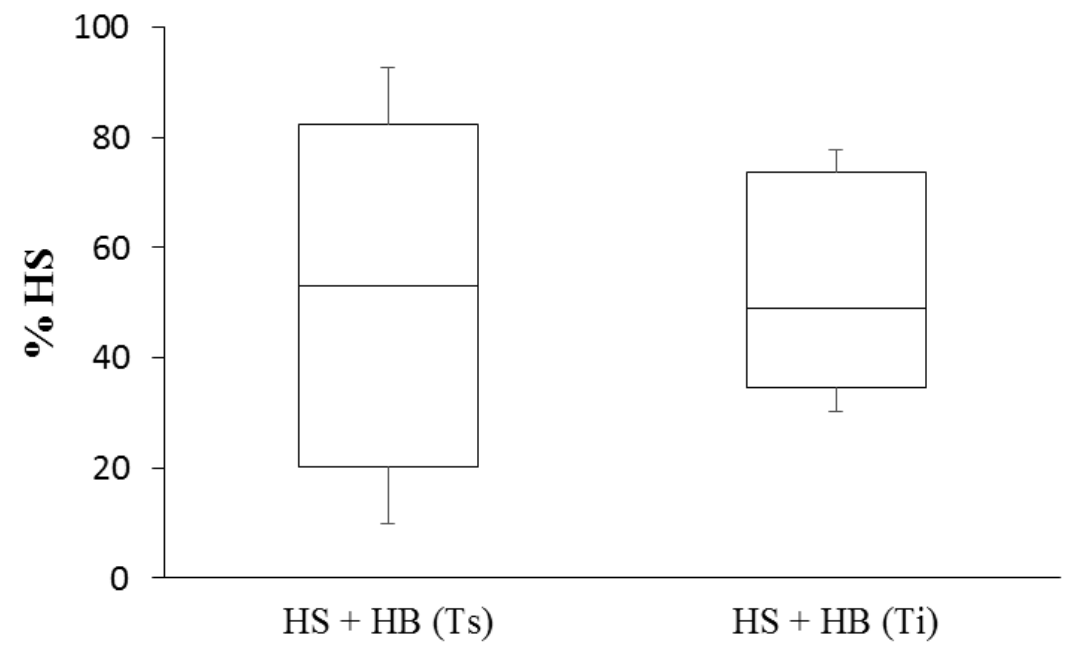

Fig. 3. Box plot of final percentages of $H$. schachtii signal raw data in treatments with $50 \%$ H. schachtii and $50 \% \mathrm{H}$. betae ( $\mathrm{HS}+\mathrm{HB}$ ) in standard temperature regime (Ts) and increased temperature regime (Ti). The minimum and maximum percentages are depicted by the whiskers, the box signifies the upper and lower quartiles, and the median is represented by a short black line within the box.

Validation of a qPCR system for quantification of the beet cyst nematode species, $\boldsymbol{H}$. schachtii and $H$. betae

A specific set of primers and probes (Table 1) was developed for both H. schachtii and H. betae. Pearson correlation analysis showed a significant correlation between microscopic counts and qPCR estimates of number of beet cyst nematodes in samples (R-Square $=0.615, \mathrm{P}=0.003$ ). Linear regression analysis revealed a positive relationship between microscopic counts and number of genes in $1 \mathrm{ml}$ samples of $\mathrm{y}=1.369 \mathrm{x}+2.133$ for $H$. schachtii and $\mathrm{y}=1.770 \mathrm{x}+0.133$ for $H$. betae (with $\mathrm{x}$ is the $\log 10$ of microscopically counted nematodes per $\mathrm{ml}$ and $\mathrm{y}$ is the $\log 10$ of the number of genes per ml). The qPCR assay was to a high degree species-specific in terms of the $H$. schachtii and $H$. betae populations used in this study. $H$. schachtii treatments, qPCR analysis resulted in $99.8 \%$ and $99.9 \% \mathrm{H}$. schachtii in standard and increased temperature regimes, respectively (Fig. 2). In the treatments containing $H$. betae also some signal for $H$. betae was detected (Fig. 2) In the H. betae treatments qPCR analysis resulted in $96,6 \%$ and $89,3 \% H$. betae in standard and increased temperature regimes, respectively. 


\section{Discussion}

In our study, increased temperature led to a significant increase in cyst nematode population numbers. Eight times more cysts, as well as second stage juveniles, were retrieved from pots cultivated at an increase in temperature of $4{ }^{\circ} \mathrm{C}$. The final nematode populations were different depending on the beet cyst nematode species present. $H$. schachtii showed the highest population density which was significantly higher than that of $H$. betae. Differences in population development at the increased temperature regime were much higher than at the standard temperature regime for all nematode treatments. Previous studies under laboratory or greenhouse conditions on the effect of temperature on the population dynamics of $H$. schachtii indicated a clear direct temperature effect, i.e. the higher the soil temperature the greater was the nematode reproduction and pathogenicity (Santo \& Bolander, 1979; Genet, 1981; Griffin, 1981, 1988).

In this study, the effect of the inoculation of the beet cyst nematode species, Heterodera schachtii and Heterodera betae, on their development was tested. The interactions between both beet cyst nematode species were expected to be mutually antagonistic as they compete for the available feeding sites (Den Nijs \& Lock, 1990). We found a higher number of cysts and juveniles of $H$. schachtii alone at the end of the experiment than from $H$. betae alone or both beet cyst nematode species mixed. Temperature has also been shown to influence the interspecific competition between cyst nematodes (Foot, 1978; Kaczmarek et al., 2014). Several competition studies report that low population densities of one nematode species were associated with the largest population densities of the other species (Umesh et al., 1994; Herve et al., 2005; Avelino et al., 2009). Soil temperature at the time of primary infection has been shown to be important in determining the dominant species in interspecific competition (Lawn, 1990). At cooler starting temperature Heterodera glycines was dominating Pratylenchus scribneri, whereas at $32{ }^{\circ} \mathrm{C} \mathrm{H}$. glycines reproduction was suppressed by $P$. scribneri (Lawn, 1990). In our study, both beet cyst nematode species performed better at higher temperatures, but there was no significant difference in the relative abundance of both species under both temperature regimes. H. betae reproduces via parthenogenetic mitosis and it could be expected that populations of $H$. schachtii which reproduces amphimictically should initially develop slower than those of $H$. betae because 
of the presumed necessity for copulation prior to reproduction (Acosta, 1980; Maas \& Heijbroek, 1982). In our study, H. schachtii showed the highest population density which was significantly higher than that of $H$. betae. Hatching studies on the tested beet cyst populations have shown that $H$. schachtii hatched within a broader temperature range and had a higher hatching rate than $H$. betae (Vandenbossche et al., 2015). However, the difference in population development at the increased temperature regime was much higher than at the standard temperature regime for all nematode treatments.

In this study, we describe a qPCR assay for detection and quantification of the two beet cyst nematode species, H. schachtii and H. betae, based on hydrolysis (TaqMan®) probes targeting the COI region. Currently, there is a range of qPCR methods that can be applied to differentiate between genera and species of plant parasitic nematodes (Berry et al., 2008; Nowaczyk et al., 2008; Toyota et al., 2008; Toumi et al., 2013). The traditional identification of Heterodera species using morphological characteristics is time-consuming and requires specialized skill, especially in the case of species mixtures. A molecular detection system for beet cyst nematodes based on the ITS-region was developed for use in a simple PCR-reaction (Amiri et al., 2002) and qPCR (Madani et al., 2005). However, prior tests with the qPCR primer system for H. schachtii resulted in a non-specific reaction (data not shown). The mitochondrial cytochrome oxidase subunit 1 (COI) gene was successfully used to discriminate between many species of free-living marine nematodes (Derycke et al., 2010) and cereal cyst nematodes (Toumi et al., 2013). A major problem that must be overcome with any qPCR assay is the design of primers and probe sets to ensure that no cross-reactions occur. We could verify that our assay was to a high degree species-specific in terms of the $H$. schachtii and $H$. betae populations used in this study. Although the qPCR analysis of the samples containing either H. schachtii or H. betae confirmed the relative proportions, we detected small percentages of $H$. schachtii signal in some $H$. betae samples, respectively. Possibly, a slight non-specific reaction of $H$. betae samples with $H$. schachtii primers might have occurred.

In conclusion, we found in our study that both beet cyst nematode species performed better at higher temperatures, but there was no significant difference in the relative abundance of both species under both temperature regimes. The final nematode populations were also different depending on the beet cyst nematode species present and were highest when only $H$. schachtii 
was present. Further studies investigating the effect of temperature on the development of both beet cyst nematodes are necessary to better understand the interactions between both cyst nematode species and to better predict the influence of increasing temperatures on beet cyst nematode population dynamics.

\section{Acknowledgements}

We thank Dr. Eckard Moll and Dr. Sven Jechalke for advice with the statistical analysis. This work was financially supported by the Ministry for Science and Culture of Lower Saxony, Germany, within the research network "KLIFF" - climate impact in Lower Saxony. 


\section{References}

Acosta, N. (1980). Effect of time lapse on pathogenicity and population dynamics of Pratylenchus alleni and P. scribneri in soybeans. Nematropica 10, 75-80.

Amiri, S., Subbotin, S. \& Moens, M. (2003). Comparative morphometrics and RAPD studies of Heterodera schachtii and $H$. betae populations. Russian Journal of Nematology 11, 9199.

Amiri, S., Subbotin, S. A. \& Moens, M. (2002). Identification of the beet cyst nematode Heterodera schachtii by PCR. European Journal of Plant Pathology 108, 497-506.

Avelino, J., Bouvret, M.-E., Salazar, L. \& Cilas, C. (2009). Relationships between agroecological factors and population densities of Meloidogyne exigua and Pratylenchus coffeae sensu lato in coffee roots, in Costa Rica. Applied Soil Ecology 43, 95-105.

Berry, S. D., Fargette, M., Spaull, V. W., Morand, S. \& Cadet, P. (2008). Detection and quantification of root-knot nematode (Meloidogyne javanica), lesion nematode ( Pratylenchus zeae) and dagger nematode (Xiphinema elongatum) parasites of sugarcane using real-time PCR. Molecular and Cellular Probes 22, 168-176.

Campos Herrera, R., Jaffuel, G., Chiriboga, X., Blanco Perez, R., Fesselet, M., Blanco Pérez, R., Půža, V. \& Mascher, F. (2015). Traditional and molecular detection methods reveal intense interguild competition and other multitrophic interactions associated with native entomopathogenic nematodes in Swiss tillage soils. Plant and Soil 389, 237-255.

Cooke, D. A. (1991). The effect of beet cyst nematode, Heterodera schachtii, on the yield of sugar beet in organic soils. Annals of Applied Biology 118, 153-160.

Den Nijs, L. J. M. F. \& Lock, C. a. M. (1990). Quantification of Globodera rostochiensis and G. pallida in mixed populations using species-specific thermostable proteins. Netherlands Journal of Plant Pathology 96, 179-186.

Derycke, S., Vanaverbeke, J., Rigaux, A., Backeljau, T. \& Moens, T. (2010). Exploring the use of cytochrome oxidase c subunit 1 (COI) for DNA barcoding of free-living marine nematodes. PLOS ONE 5, e13716.

Fleming, C., Turner, S. J., Powers, T. \& Szalansky, A. (1998). Diagnostics of cyst nematodes: use of the polymerase chain reaction to determine species and estimate population levels. Aspects of Applied Biology 52, 375-382.

Foot, M. A. (1978). Temperature responses of three potato-cyst nematode populations from New Zealand. Nematologica 24, 412-417.

Franco, J. (1979). Effect of temperature on hatching and multiplication of potato cyst nematodes. Nematologica 25, 237-244.

Genet, R. A. (1981). An evaluation of 3 potato cultivars resistant to Globodera rostochiensis. New Zealand Journal of Experimental Agriculture 9, 101-104. 
Gracianne, C., Petit, E., Arnaud, J.-F., Porte, C., Renault, L., Fouville, D., Rouaux, C. \& Fournet, S. (2014). Spatial distribution and basic ecology of Heterodera schachtii and H. betae wild populations developing on sea beet, Beta vulgaris ssp. maritima. Nematology 16, 797-805.

Griffin, G. (1981). The relationship of plant age, soil temperature, and population density of Heterodera schachtii on the growth of sugarbeet. Journal of Nematology 13, 184.

Griffin, G. (1988). Factors affecting the biology and pathogenicity of Heterodera schachtii on sugarbeet. Journal of Nematology 20, 396-404.

Herve, G., Bertrand, B., Villain, L., Licardie, D. \& Cilas, C. (2005). Distribution analyses of Meloidogyne spp. and Pratylenchus coffeae sensu lato in coffee plots in Costa Rica and Guatemala. Plant Pathology 54, 471-475.

Kaczmarek, A., Mackenzie, K., Kettle, H. \& Blok, V. (2014). Influence of soil temperature on Globodera rostochiensis and Globodera pallida. Phytopathologia Mediterranea 53, 396405.

Kakaire, S., Grove, I. \& Haydock, P. (2012). Effect of temperature on the life cycle of Heterodera schachtii infecting oilseed rape (Brassica napus L.). Nematology 14, 855867.

Lawn, D. A. (1990). Effects of temperature on competition between Heterodera glycines and Pratylenchus scribneri on soybean. Nematropica 20, 57-69.

Maas, P. W. T. \& Heijbroek, W. (1982). Biology and pathogenicity of the yellow beet cyst nematode; a host race of Heterodera trifolii on sugar beet in the Netherlands. Nematologica 28, 77-93.

Madani, M., Subbotin, S. A. \& Moens, M. (2005). Quantitative detection of the potato cyst nematode, Globodera pallida, and the beet cyst nematode, Heterodera schachtii, using Real-Time PCR with SYBR green I dye 29. Molecular and Cellular Probes 19, 81-86.

Müller, J. \& Rumpenhorst, H. (2000). Die Prüfung von Pflanzen auf ihre Widerstandsfähigkeit gegen Schadorganismen in der Biologischen Bundesanstalt. Teil 1 Prüfung von Kulturpflanzen auf Resistenz gegen pflanzenparasitäre Nematoden. Mitt. Biol. Bundesanst. Land-Forstwirtsch. Berlin-Dahlem 372, 38.

Neilson, R. \& Boag, B. (1996). The predicted impact of possible climatic change on virus-vector nematodes in Great Britain. European Journal of Plant Pathology 102, 193-199.

Nowaczyk, K., Dobosz, R., Kornobis, S. \& Obrepalska-Steplowska, A. (2008). TaqMan realtime PCR-based approach for differentiation between Globodera rostochiensis (golden nematode) and Globodera artemisiae species. Parasitology Research 103, 577-581.

Powers, T. (2004). Nematode molecular diagnostics: from bands to barcodes. Annu. Rev. Phytopathol. 42, 367-383. 
Santo, G. \& Bolander, W. (1979). Interacting effects of soil temperature and type on reproduction and pathogenicity of Heterodera schachtii and Meloidogyne hapla on sugarbeets. Journal of Nematology 11, 289-291.

Shepherd, A. (1986). Extraction and estimation of cyst nematodes. Laboratory methods for work with plant and soil nematodes, 31-49.

Torr, P., Spiridonov, S. E., Heritage, S. \& Wilson, M. J. (2007). Habitat associations of two entomopathogenic nematodes: a quantitative study using real-time quantitative polymerase chain reactions. Journal of Animal Ecology 76, 238-245.

Toyota, K., Shirakashi, T., Sato, E., Wada, S. \& Min, Y. Y. (2008). Development of a real-time PCR method for the potato-cyst nematode Globodera rostochiensis and the root-knot nematode Meloidogyne incognita. Soil science and plant nutrition 54, 72-76.

Toumi, F., Waeyenberge, L., Viaene, N., Dababat, A., Nicol, J. M., Ogbonnaya, F. \& Moens, M. (2013). Development of a species-specific PCR to detect the cereal cyst nematode, Heterodera latipons. Nematology 15, 709-717.

Trudgill, D. (1995). An assessment of the relevance of thermal time relationships to nematology. Fundamental and Applied Nematology 18, 407-417.

Umesh, K. C., Ferris, H. \& Bayer, D. E. (1994). Competition between the plant-parasitic nematodes Pratylenchus neglectus and Meloidogyne chitwoodi. Journal of Nematology 26, 286-95.

Vandenbossche, B., Niere, B. \& Vidal, S. (2015). Effect of temperature on the hatch of two German populations of the beet cyst nematodes, Heterodera schachtii and Heterodera betae. Journal of Plant Diseases and Protection 122, 250-254. 


\section{Chapter 5:}

\section{General discussion}

Differences in temperature effects on the development of Heterodera schachtii and Heterodera betae

Different nematode species have different optimum temperatures for feeding, hatching, reproduction and survival (Neilson \& Boag, 1996), hence their development is strongly influenced by the microclimate.

In chapter 2, the optimal temperatures for hatch were found to be different for both cyst nematode species. The optimal temperature range for hatch of $H$. schachtii was found to be between 15 and $30^{\circ} \mathrm{C}$ and for $\mathrm{H}$. betae between 20 and $30^{\circ} \mathrm{C}$. Hatch of $\mathrm{H}$. schachtii at $15^{\circ} \mathrm{C}$ and $20{ }^{\circ} \mathrm{C}$ was, although not significantly, lower, than at $25{ }^{\circ} \mathrm{C}$ and $30{ }^{\circ} \mathrm{C}$, suggesting that 15 till 20 ${ }^{\circ} \mathrm{C}$ is only a sub-optimal temperature range for hatch of the studied $H$. schachtii population. Emergence of juveniles of both beet species began at $5{ }^{\circ} \mathrm{C}$, however in very low percentages. $H$. schachtii displayed a broader temperature range over which similar cumulative hatching rates occurred in comparison with $H$. betae. For both beet cyst nematode species no significant differences were found in the final cumulative hatch percentages when comparing the standard and the $4{ }^{\circ} \mathrm{C}$ increased temperature regime.

In chapter 4, increased temperature led to a significant increase in beet cyst nematode numbers. The final nematode populations were also different depending on the beet cyst nematode species present. $H$. schachtii showed the highest population density which was significantly higher than that of $H$. betae. Further, the effect of co-infection of the beet cyst nematode species, $H$. schachtii and $H$. betae, on their population development was tested. The interactions between both beet cyst nematode species were expected to be mutually antagonistic as they compete for the available feeding sites (Den Nijs \& Lock, 1990). Temperature has been shown to influence the competitive dominance of cyst nematodes (Foot, 1978; Kaczmarek et al., 2014) as soil temperature at the time of primary infection has been shown to be important in determining the dominant species in interspecific competition (Lawn, 1990). In this study, both beet cyst 
nematode species developed better at higher temperatures, but there was no significant difference in the relative abundance of both species under both temperature regimes. We found a higher number of cysts and juveniles of $H$. schachtii alone at the end of the experiment than from $H$. betae alone or both beet cyst nematode species mixed.

\section{Experimental methods in climate change studies}

A variety of experimental approaches, such as infrared heaters, open top chambers, and heating mats have been used to study climate change effects under field conditions in different environments. Our results (chapter 3) show that a heating mat system allows studying the effects of soil warming attributed to climate change on nematode density and crop performance under outdoor conditions. Experimental soil heating led to an increased nematode development on the susceptible beet cultivar, but not on the resistant cultivar. However, the applied approach also comes with some limitations. Indeed, the temperature difference was higher at low ambient temperatures and lower at high ambient temperatures. The temperature is higher closer to the heating mat, which could influence nematode development. The combination of belowground soil warming and aboveground heaters (Thakur et al., 2014) should therefore be explored for studying effects of soil warming on nematode development and crop performance. Alternatively, free air $\mathrm{CO}_{2}$ enrichment studies offer a lot of opportunities as climate change is simulated with minimal impacts on the study system (Long et al., 2004; Ainsworth \& Long, 2005)

\section{Other climatic factors influencing host-parasite interactions}

This work focused on elevated temperatures as a result of climate change. However, other climatic factors such as increased $\mathrm{CO}_{2}$ increased surface ozone, and soil moisture may influence nematode populations.

\section{Carbon dioxide}

Crop sense and respond directly to rising $\mathrm{CO}_{2}$ through photosynthesis and stomatal conductance, and this forms the basis for the CO2 fertilization effect on yield (Long et al., 2004). Specifically for sugar beet, an increase in storage root yield of $12.1 \%$ can be expected (Weigel \& Manderscheid, 2012). Due to observations that elevated $\mathrm{CO}_{2}$ increases root production (Rogers et al., 1994; Kimball \& Sparks, 2001), it can be expected that this will also affect plant parasitic 
nematodes. Effects of increased carbon dioxide on nematode abundance range from being positive (Yeates et al., 1997; Yeates et al., 1999), neutral, or negative (Hoeksema et al., 2000). However, most studies report neutral effects (Hungate et al., 2000; Sonnemann \& Wolters, 2005)

\section{Surface ozone}

Increased combustion of fuels will increase not only atmospheric $\mathrm{CO}_{2}$ but also atmospheric nitrogen oxide concentrations, which, when coupled with climate change, will result in a continuous increase in surface ozone $\left(\mathrm{O}_{3}\right)$ concentration (Long, 2006). Contrastingly, the stratospheric $\mathrm{O}_{3}$ layer is getting depleted by man-made chloride and bromide compounds which lead to an increment solar radiation approaching the earth (Bao et al., 2014). Surface ozone can have negative effects on the reproduction of and development of cyst nematodes (Weber et al., 1979) and on the community structure and functional diversity of soil nematodes (Bao et al., 2013). The application of ozone gas has also been tested as a nematode control strategy (Qiu $e t$ al., 2009; Msayleb \& Ibrahim, 2011)

\section{Solar radiation}

The effect of UV-B on plant performance varies by species and cultivar (Heisler et al., 2003), but generally rising UV-B are expected to have detrimental effects on crop yield (Kakani et al., 2003). Reports on the influence of enhanced UV-B radiation on nematode abundance in soil are contradictory with either negative (Koti et al., 2007) or positive (Bao et al., 2014) effects.

\section{Soil moisture}

Nematodes are basically aquatic organisms and require water for their activity. Either too high or too low moisture levels in soil affects the nematodes (Jones et al., 1969). Decreases in summer rainfall and soil moisture projected by climate models for temperate regions are likely to adversely affect plant parasitic nematodes (Garrett et al., 2006). However, the independence of moisture stress and nematode stress on crops is fairly common (Davis et al., 2014).

\section{Interactions between climatic factors}


Climate change can rarely be described by single parameter changes as different climatic factors interact, so ideally large multifactorial experiments are required to unravel their combined effect (Garrett et al., 2006).

\section{Global warming and beet cyst nematode management}

The interaction between the beet cyst nematodes and sugar beet remains relevant due as this pest can lead to serious yield losses. Understanding these interactions and the climatic factors influencing these interactions is vital towards the development of management strategies. Farmers have been dealing with climatic variability between years successfully in the past and they are likely to cope well with future climatic change (Siebold, 2013). Rising temperatures may be beneficial for farmers in Germany, since the extended growing season may allow more flexibility in sowing and harvesting dates. Although increasing temperatures could have a positive effect on sugar beet yield due to faster development, this effect can be mitigated due to earlier incidence of beet cyst nematodes (Racca et al., 2015).

Temperature has also been reported to influence the pathogenicity of beet cyst nematodes, so that the damage threshold of $H$. schachtii on sugar beet grown in Germany decreased from $20 \mathrm{eggs} \mathrm{g}^{-1}$ soil in April to $2.5 \mathrm{eggs}^{-1}$ soil in May as a result of an increase in soil temperature at planting (Steudel \& Thielemann, 1970). Furthermore, increased nematode damage can produce entry ports for fungi to enter inside the plants (Hilnhütter, 2010).

Besides global warming, political frameworks may influence the future importance of nematodes in sugar beet production (Belboom \& Léonard, 2012). For example, the EU directive 2009/28/EC for the promotion of the use of energy from renewable sources, will lead to an increasing cultivation of renewable resources like oilseed rape and sugar beet (Belboom \& Léonard, 2012; Siebold, 2013). Interestingly, oilseed rape is also a good host for H. schachtii. Increased sugar beet and oilseed rape cultivation, however, will lead to enhanced pathogen pressure.

Climate change will also affect pest management with regards to timing, preference, and efficacy of the different measures (Juroszek \& von Tiedemann, 2011). Possible effects of climate change on selected beet cyst nematode management measures are listed below: 


\section{Crop rotation}

Crop species better adapted to local climatic conditions may be required (Juroszek \& von Tiedemann, 2011).

\section{Sowing and harvesting date}

Climate change will presumably change the optimal choice of sowing/planting date, which is a simple a cheap method to escape biotic and abiotic stress (Juroszek \& von Tiedemann, 2011). Harvest date has a high influence on population dynamics of $H$. schachtii (Hauer et al., 2016). As such, a strong decrease in field nematode populations is possible when the host plants are removed before nematodes could fulfill their life cycle (Hauer et al., 2016).

\section{Cultivar choice}

The use of tolerant and resistant cultivars is a cheap, environmentally sound and effective method in beet cyst nematode management (Niere, 2009; Juroszek \& von Tiedemann, 2011). As climate change induced increased temperatures can reduce host plant resistance (Barbetti et al., 2012), it is relevant that cultivar performances are tested under climate change scenarios. In chapter 3, we found that the plant-nematode interaction can vary considerably depending on the planted cultivar. We found that increased soil temperatures lead to a significant increase in the final number of recovered cysts on the tolerant cultivar and susceptible cultivar, but not on the resistant cultivar. The resistant cultivar did not allow nematode reproduction at all. Thus cultivar choice, and especially the use of resistant cultivars, will continue to be an important element when trying to prevent nematode infestation or controlling nematode populations in the field.

\section{Trap crops}

Trap crops are cultivated before sugar beet on more than $40 \%$ of the German sugar beet cropping areas, often to reduce nematode population, but also to improve yield (Hauer et al., 2016). Under favourable conditions, reduction of up to $70 \%$ of the population can be achieved while maintaining the sugar beet yield on a high level (Heinrichs, 2011). However, the nematode reduction effect depends on high degree of the trap crop variety and environmental conditions (Niere, 2009). An early sowing date immediate after harvesting is a prerequisite to establish trap crop stands producing sufficiently high biomass and rooting density (Hauer et al., 2016). In the 
case that climate changes allows earlier sowing, this could positively influence the efficacy of nematode trap crops.

\section{Chemical control}

In Europe, nematicides are not registered for use in sugar beets (Niere, 2009; Hauer et al., 2016). Recent test trials of a nematicide development product based on Abamectin did not show efficacy against beet cyst nematodes (Hauer et al., 2016).

\section{Biologic control}

Natural antagonists of $H$. schachtii are diverse and their suppressive effect is important in the natural decline of field populations (Westphal \& Becker, 1999, 2001; Niere, 2009). Transferring of the suppressiveness was successful under experimental conditions, but is still not established in practice (Niere, 2009). The practical establishment of the entomopathogenic fungus Hirsutella rhossiliensis as a biological control agent was not successful (Gutberlet, 2000; Slaats, 2007). Climate changes may differentially affect the physical distribution and/or phenology of host, agent, and target, which can influence biocontrol efficacy (Ziska \& McConnell, 2015).

To conclude, rising temperature is one among multiple climatic factors that can stimulate the incidence and impact of beet cyst nematodes on sugar beet production. Hereby, relative contributions of $H$. schachtii and $H$. betae will probably not drastically change. In case of high nematode population densities and with the expected increasing soil temperatures, planting nematode-resistant cultivars will become even more important in the future, as an effective tool to reduce nematode populations and prevent damages. 


\section{References}

Ainsworth, E. A. \& Long, S. P. (2005). What have we learned from 15 years of free-air $\mathrm{CO}_{2}$ enrichment (FACE)? A meta-analytic review of the responses of photosynthesis, canopy properties and plant production to rising $\mathrm{CO}_{2}$. New Phytologist 165, 351-372.

Bao, X., Li, Q., Hua, J., Zhao, T. \& Liang, W. (2014). Interactive effects of elevated ozone and UV-B radiation on soil nematode diversity. Ecotoxicology 23, 11-20.

Barbetti, M. J., Banga, S. S. \& Salisbury, P. A. (2012). Challenges for crop production and management from pathogen biodiversity and diseases under current and future climate scenarios-case study with oilseed Brassicas. Field Crops Research 127, 225-240.

Belboom, S. \& Léonard, A. (2012). Improving bioethanol production by increasing sugar beet crop yield. Plant Sciences Reviews 2011, 49-58.

Cooke, D. (1987). Beet cyst nematode (Heterodera schachtii Schmidt) and its control on sugar beet. Agricultural Zoology Reviews 2, 132-183.

Davis, R. F., Earl, H. J. \& Timper, P. (2014). Effect of simultaneous water deficit stress and Meloidogyne incognita infection on cotton yield and fiber quality. Journal of Nematology 46, 108-118.

Den Nijs, L. J. M. F. \& Lock, C. a. M. (1990). Quantification of Globodera rostochiensis and G. pallida in mixed populations using species-specific thermostable proteins. Netherlands Journal of Plant Pathology 96, 179-186.

Foot, M. A. (1978). Temperature responses of three potato-cyst nematode populations from New Zealand. Nematologica 24, 412-417.

Garrett, K. A., Dendy, S. P., Frank, E. E., Rouse, M. N. \& Travers, S. E. (2006). Climate Change Effects on Plant Disease: Genomes to Ecosystems. Annual Review of Phytopathology 44, 489-509.

Gracianne, C., Petit, E., Arnaud, J.-F., Porte, C., Renault, L., Fouville, D., Rouaux, C. \& Fournet, S. (2014). Spatial distribution and basic ecology of Heterodera schachtii and H. betae wild populations developing on sea beet, Beta vulgaris ssp. maritima. Nematology 16, 797-805.

Gutberlet, V. (2000). Untersuchungen zur Eignung der Verkapselung des nematophagen Pilzes Hirsutella rhossiliensis für die biologische Bekämpfung von Heterodera schachtii und Meloidogyne incognita unter Verwendung nachwachsender Rohstoffe. Institut für Pflanzenkrankheiten der Rheinischen Friedrich-Wilhelms-Universität Bonn. PhD thesis.

Hauer, M., Koch, H. J., Krüssel, S., Mittler, S. \& Märländer, B. (2016). Integrated control of Heterodera schachtii Schmidt in Central Europe by trap crop cultivation, sugar beet variety choice and nematicide application. Applied Soil Ecology 99, 62-69. 
Heinrichs, C. (2011). Biologische Bekämpfung des Rübenzystennematoden Heterodera schachtii. Gesunde Pflanzen 62, 101-106.

Heisler, G. M., Grant, R. H., Gao, W. \& Slusser, J. R. (2003). Ultraviolet radiation and its impacts on agriculture and forests. Agricultural and Forest Meteorology 120, 3-7.

Hoeksema, J. D., Lussenhop, J. \& Teeri, J. A. (2000). Soil nematodes indicate food web responses to elevated atmospheric $\mathrm{CO}_{2}$. Pedobiologia 44, 725-735.

Hillnhütter, C. (2011). Non-destructive evaluation of complex interactions between Heterodera schachtii and Rhizoctonia solani on sugar beet as affected by cultivar resistance. $\mathrm{PhD}$ thesis.

Hungate, B. A., Jaeger Iii, C. H., Gamara, G., Chapin Iii, F. S. \& Field, C. B. (2000). Soil microbiota in two annual grasslands: responses to elevated atmospheric $\mathrm{CO}_{2}$. Oecologia 124, 589-598.

Jones, F. G. W., Larbey, D. W. \& Parrott, D. M. (1969). The influence of soil structure and moisture on nematodes, especially Xiphinema, Longidorus, Trichodorus and Heterodera spp. Soil Biology and Biochemistry 1, 153-165.

Juroszek, P. \& Von Tiedemann, A. (2011). Potential strategies and future requirements for plant disease management under a changing climate. Plant Pathology 60, 100-112.

Kaczmarek, A., Mackenzie, K., Kettle, H. \& Blok, V. (2014). Influence of soil temperature on Globodera rostochiensis and Globodera pallida. Phytopathologia Mediterranea 53, 396405.

Kakani, V. G., Reddy, K. R., Zhao, D. \& Sailaja, K. (2003). Field crop responses to ultraviolet-B radiation: a review. Agricultural and Forest Meteorology 120, 191-218.

Kimball, B. A. \& Sparks, D. L. (2001). Responses of agricultural crops to free-air $\mathrm{CO}_{2}$ enrichment. Advances in Agronomy. 293-368 pp.

Koti, S., Reddy, K. R., Lawrence, G., Reddy, V., Kakani, V., Zhao, D. \& Gao, W. (2007). Effect of enhanced UV-B radiation on reniform nematode (Rotylenchus reniformis Linford and Oliveira) populations in cotton (Gossypium hirsutum L.). Plant Pathology Journal.

Lawn, D. A. (1990). Effects of temperature on competition between Heterodera glycines and Pratylenchus scribneri on soybean. Nematropica 20, 57-69.

Long, S., Ainsworth, E., Rogers, A. \& Ort, D. (2004). Rising atmospheric carbon dioxide: Plants FACE the Future. Annual Review of Plant Biology 55, 591-628.

Long, S. P. (2006). Food for thought: Lower-than-expected crop yield stimulation with rising $\mathrm{CO}_{2}$ concentrations. Science 312, 1918-1921.

Maas, P. W. T. \& Heijbroek, W. (1982). Biology and pathogenicity of the yellow beet cyst nematode; a host race of Heterodera trifolii on sugar beet in the Netherlands. Nematologica 28, 77-93. 
Msayleb, N. \& Ibrahim, S. (2011). Treatment of nematodes with ozone gas: A sustainable alternative to nematicides. Physics Procedia 21, 187-192.

Neilson, R. \& Boag, B. (1996). The predicted impact of possible climatic change on virus-vector nematodes in Great Britain. European Journal of Plant Pathology 102, 193-199.

Niere, B. (2009). Principles of beet cyst nematode management. Sugar Industry/Zuckerindustrie 134, 186-192.

Qiu, J. J., Westerdahl, B. B. \& Pryor, A. (2009). Reduction of root-knot nematode, Meloidogyne javanica, and ozone mass transfer in soil treated with ozone. Journal of Nematology 41, 241-246.

Racca, P., Kakau, J., Kleinhenz, B. \& Kuhn, C. (2015). Impact of climate change on the phenological development of winter wheat, sugar beet and winter oilseed rape in Lower Saxony, Germany. Journal of Plant Diseases and Protection 122, 16-27.

Rogers, H., Runion, G. B. \& Krupa, S. (1994). Plant responses to atmospheric CO2 enrichment with emphasis on roots and the rhizosphere. Environmental pollution 83, 155-189.

Siebold, M. (2013). Effects of rising air and soil temperatures on the life cycle of important pathogens in oilseed rape (Brassica napus L.) in Lower Saxony. Niedersächsische Staatsund Universitätsbibliothek Göttingen. PhD thesis.

Slaats, B. (2007). Investigations on the efficacy of encapsulation of the endoparasitic fungus Hirsutella rhossiliensis for control of plant-parasitic nematodes. Rheinische FriedrichWilhelms-Universität Bonn. PhD thesis.

Sonnemann, I. \& Wolters, V. (2005). The microfood web of grassland soils responds to a moderate increase in atmospheric $\mathrm{CO}_{2}$. Global Change Biology 11, 1148-1155.

Steudel, W. \& Thielemann, R. (1970). Weitere Untersuchungen zur Frage der Empfindlichkeit von Zuckerrüben gegen den Rübennematoden (Heterodera schachtii Schmidt). Zucker 23, 106-109.

Thakur, M., Reich, P., Fisichelli, N., Stefanski, A., Cesarz, S., Dobies, T., Rich, R., Hobbie, S. \& Eisenhauer, N. (2014). Nematode community shifts in response to experimental warming and canopy conditions are associated with plant community changes in the temperateboreal forest ecotone. Oecologia 175, 713-723.

Weber, D., Reinert, R. \& Barker, K. (1979). Ozone and sulfur dioxide effects on reproduction and host-parasite relationships of selected plant-parasitic nematodes. Phytopathology 69, 624-628.

Weigel, H.-J. \& Manderscheid, R. (2012). Crop growth responses to free air $\mathrm{CO}_{2}$ enrichment and nitrogen fertilization: Rotating barley, ryegrass, sugar beet and wheat. European Journal of Agronomy 43, 97-107.

Westphal, A. \& Becker, J. O. (1999). Biological suppression and natural population decline of Heterodera schachtii in a California field. Phytopathology 89, 434-440. 
Westphal, A. \& Becker, J. O. (2001). Soil suppressiveness to Heterodera schachtii under different cropping sequences. Nematology 3, 551-558.

Yeates, G., Tate, K. \& Newton, P. (1997). Response of the fauna of a grassland soil to doubling of atmospheric carbon dioxide concentration. Biology and Fertility of Soils 25, 307-315.

Yeates, G. W., Newton, P. C. \& Ross, D. J. (1999). Response of soil nematode fauna to naturally elevated $\mathrm{CO}_{2}$ levels influenced by soil pattern. Nematology 1, 285-293.

Ziska, L. H. \& Mcconnell, L. L. (2015). Climate change, carbon dioxide, and pest biology: Monitor, mitigate, manage. Journal of Agricultural and Food Chemistry. 


\section{DECLARATIONS}

1. I, hereby, declare that this $\mathrm{Ph} . \mathrm{D}$. dissertation has not been presented to any other examining body either in its present or a similar form. Furthermore, I also affirm that I have not applied for a Ph.D. at any other higher school of education.

Göttingen,

(Signature)

Bart Vandenbossche

2. I, hereby, solemnly declare that this dissertation was undertaken independently and without any unauthorised aid.

Göttingen,

(Signature)

Bart Vandenbossche 